\title{
Immunological properties of oxygen-transport proteins: hemoglobin, hemocyanin and hemerythrin
}

\author{
Christopher J. Coates $^{1} \cdot$ Heinz Decker ${ }^{2}$
}

Received: 31 May 2016/Revised: 17 July 2016/Accepted: 3 August 2016/Published online: 12 August 2016

(C) The Author(s) 2016. This article is published with open access at Springerlink.com

\begin{abstract}
It is now well documented that peptides with enhanced or alternative functionality (termed cryptides) can be liberated from larger, and sometimes inactive, proteins. A primary example of this phenomenon is the oxygen-transport protein hemoglobin. Aside from respiration, hemoglobin and hemoglobin-derived peptides have been associated with immune modulation, hematopoiesis, signal transduction and microbicidal activities in metazoans. Likewise, the functional equivalents to hemoglobin in invertebrates, namely hemocyanin and hemerythrin, act as potent immune effectors under certain physiological conditions. The purpose of this review is to evaluate the true extent of oxygen-transport protein dynamics in innate immunity, and to impress upon the reader the multi-functionality of these ancient proteins on the basis of their structures. In this context, erythrocyte-pathogen antibiosis and the immune competences of various erythroid cells are compared across diverse taxa.
\end{abstract}

Keywords Antimicrobial peptides - Innate immunity · Myoglobin · Phenoloxidase - Erythrocytes · Enzyme promiscuity $\cdot$ Metabolism $\cdot$ Redox

Electronic supplementary material The online version of this article (doi:10.1007/s00018-016-2326-7) contains supplementary material, which is available to authorized users.

Christopher J. Coates

c.j.coates@swansea.ac.uk

1 Department of Biosciences, College of Science, Swansea University, Singleton Park, Swansea, Wales SA2 8PP, UK

2 Institut für Molekulare Biophysik, Johannes GutenbergUniversität Mainz, Jakob Welder-Weg 28, 55128 Mainz, Germany

\author{
Abbreviations \\ AMP Antimicrobial peptide \\ 2-DIGE 2-Dimensional gel electrophoresis \\ GE-Hb Giant extracellular hemoglobin \\ Hp Haptoglobin \\ $\mathrm{Hb} \quad$ Hemoglobin \\ Hc Hemocyanin \\ $\mathrm{Hr} \quad$ Hemerythrin \\ IFN Interferon \\ LPS Lipopolysaccharide \\ LTA Lipoteichoic acid \\ metHb Methemoglobin \\ $\mathrm{Mb} \quad$ Myoglobin \\ PRR Pathogen recognition receptor \\ PAMP Pathogen associated molecular pattern \\ PGN Peptidoglycan \\ PO Phenoloxidase \\ RBCs Red blood cells \\ RNS Reactive nitrogen species \\ ROS Reactive oxygen species \\ SDS Sodium dodecyl sulphate \\ SNPs Single nucleotide polymorphisms \\ TLR Toll-like receptor \\ WBCs White blood cells
}

\section{Introduction}

Maintaining immunity-related proteostasis in metazoans is crucial to survival and recovery from biotic (pathogenic) and abiotic (environmental) traumas. Enlisting oxygentransport proteins (OTPs: hemoglobin and hemocyanin) to directly combat microbes as well as to supply the $\mathrm{O}_{2}$ necessary to fuel the costly immuno-metabolome is both 
resourceful and economical. The concentration of oxygen within wounds determines a hosts' ability to heal and to resist microbial colonisation [1, 2]. Hypoxia and inadequate oxygen tension within tissues can compromise immune cell functionality, e.g. restricting neutrophil respiratory burst [3].

With representatives in almost every known taxon, hemoglobin $(\mathrm{Hb})$, hemocyanin $(\mathrm{Hc})$ and hemerythrin $(\mathrm{Hr})$ are metallated proteins responsible primarily for the sensing, transport and/or storage of $\mathrm{O}_{2}$ [4]. $\mathrm{Hb}$ and $\mathrm{Hr}$ are located within the corpuscles (erythrocytes) of vertebrate blood and specialised immune cells (hemerythrocytes) of invertebrate coelomic fluid ${ }^{1}$, respectively [5]. Conversely, Hcs are freely dissolved within the hemolymph plasma of some molluscs and arthropods. Although present in fewer species, it must be noted that two other forms of hemebased OTPs exist, namely chlorocruorin and erythrocruorin from annelids (often referred to as giant extracellular hemoglobins: GE-Hbs) [6-8].

Reports of Hb's involvement in anti-infective defences have existed since the late 1950s [9], yet only in the last two decades has it become evident that $\mathrm{Hb}, \mathrm{Hc}$, and to a lesser extent $\mathrm{Hr}$, contribute to various innate immune mechanisms. Generation of bioactive peptides (cryptides), enzyme promiscuity and pro-inflammatory signalling are but some of the many functions attributed to OTPs, which are expanded upon herein.

\section{The oxygen-transport proteins}

\section{Hemoglobins}

The presence and diversity of hemoglobins (Hbs) have been confirmed in metazoans, prokaryotes, fungi and flora, with a notable absence in icefish. A common ancestor for globin-related respiratory proteins existed over 1.5 billion years ago [reviewed by 10]. In excess of 250 million $\mathrm{Hb}$ molecules are packaged tightly within each human erythrocyte, guaranteeing their stability against proteolysis, a low colloid osmotic pressure, and preventing loss by filtration in the kidneys. $\mathrm{Hb}$ concentration within healthy adults ranges from 120 to $160 \mathrm{mg} \mathrm{mL}^{-1}$ [11].

Vertebrate $\mathrm{Hb}$ consists of two identical $\alpha$-chains and two identical $\beta$-chains with molecular masses of $\sim 16 \mathrm{kDa}$ each. Two $\alpha \beta$-dimers assemble in $C 2$ symmetry to form the $\mathrm{Hb}$ tetramer ( $\sim 64 \mathrm{kDa})$ (Fig. 1). Individual subunits are comparable to monomeric myoglobin $(\mathrm{Mb})$, and in all cases, $\mathrm{Hb}$ and $\mathrm{Mb}$ fold into a nest of $\alpha$-helices [12]. Heme prosthetic groups are present in each subunit, consisting of

\footnotetext{
${ }^{1}$ Hemolymph and coelomic fluid are the invertebrate equivalents to blood.
}

a protoporphyrin ring and a single iron ion in the centre that is coordinated by the proximal histidine of $\alpha$-helix F. At the other side of the heme, oxygen binds reversibly to the iron in an "end on" coordination (Fig. 1). Binding of oxygen to $\mathrm{Hb}$ induces a conformational rotation $\left(15^{\circ}\right)$ of one $\alpha \beta$ dimer against the other, thus switching from a tense (T) deoxygenated state to a relaxed (R) oxygenated state. Cooperative oxygen binding can be modulated by an allosteric effector such as 2,3-diphosphoglycerate in human $\mathrm{Hb}$ along the symmetry axis of the tetramer [12]. Vertebrate myoglobins (Mbs) are oxygen storage proteins in red muscle (e.g. cardiac) and other tissues, working to build up a $\mathrm{pO}_{2}$ gradient from blood vessels to mitochondria for ATP synthesis [13].

Extracellular Hbs (or erythrocruorins) are mostly large, oligomeric proteins with molecular masses up to 3.6 MDa. Vinogradov (1985) classified them into four separate groups: (a) single-domain, single-subunit Hbs $(\sim 16 \mathrm{kDa})$ found in trematodes and some insects, (b) two-domain, multi-subunit $\mathrm{Hbs}$ in branchiopod crustaceans such as Daphnia and Triops, (c) multi-domain, multi-subunit Hbs in carapace-free brachiopod crustaceans, the planorbid snails and some clams ( $\sim 1.7 \mathrm{MDa})$ and (d) single-domain, multi-subunit $\mathrm{Hb}$ aggregates ca. 3.6 MDa in annelids [14]. The first resolved structure of a GE-Hb was from the earthworm, Lumbricus terrestris [6]. This mega-molecule consisted of $144 \mathrm{Hbs}$ and 36 linker subunits assembled to form a core complex with $D 6$ symmetry. Recently, the quaternary structure of Glossoscolex paulistus plasma $\mathrm{Hb}$ was presented with a resolution of $3.2 \AA$, which is the highest resolution reported for a hexagonal bilayer $\mathrm{Hb}$ with 12 protomers [15].

\section{Hemocyanins}

Although strikingly different in structural appearance, both arthropod and mollusc Hcs contain dicupric (histidine coordinated) groups that reversibly bind molecular oxygen in a side on $\left(\mu-\eta^{2}: \eta^{2}\right)$ bridging coordination [16] (Fig. 1). Arthropod $\mathrm{Hc}$ is composed of kidney-shaped subunits ( $\sim 72 \mathrm{kDa}$, each with an oxygen binding site) arranged into hexamers (Fig. 1) [17]. Hexamers are formed when three subunits assemble back to back and dimerize isologously with a second trimer along the rotational axis (but are twisted against each other by $60^{\circ}$ ). Individual hexamers or multiples of hexamers have been observed in vitro, the largest of these is an $8 \times 6$ mer $(\sim 3.4 \mathrm{MDa})$ purified from horseshoe crab genera Limulus and Tachypleus. Invertebrate $\mathrm{Hcs}$ and GE-Hbs show strong hierarchies in structural organisation corresponding to hierarchical allosteric interactions ('nesting') $[18,19]$.

$\mathrm{Hc}$ concentration in the hemolymph varies greatly depending on the species, $\sim 20-80 \mathrm{mg} \mathrm{mL}^{-1}$. In extreme 


\section{Hemoglobin}

\section{Hemocyanins}

\section{Hemerythrin}
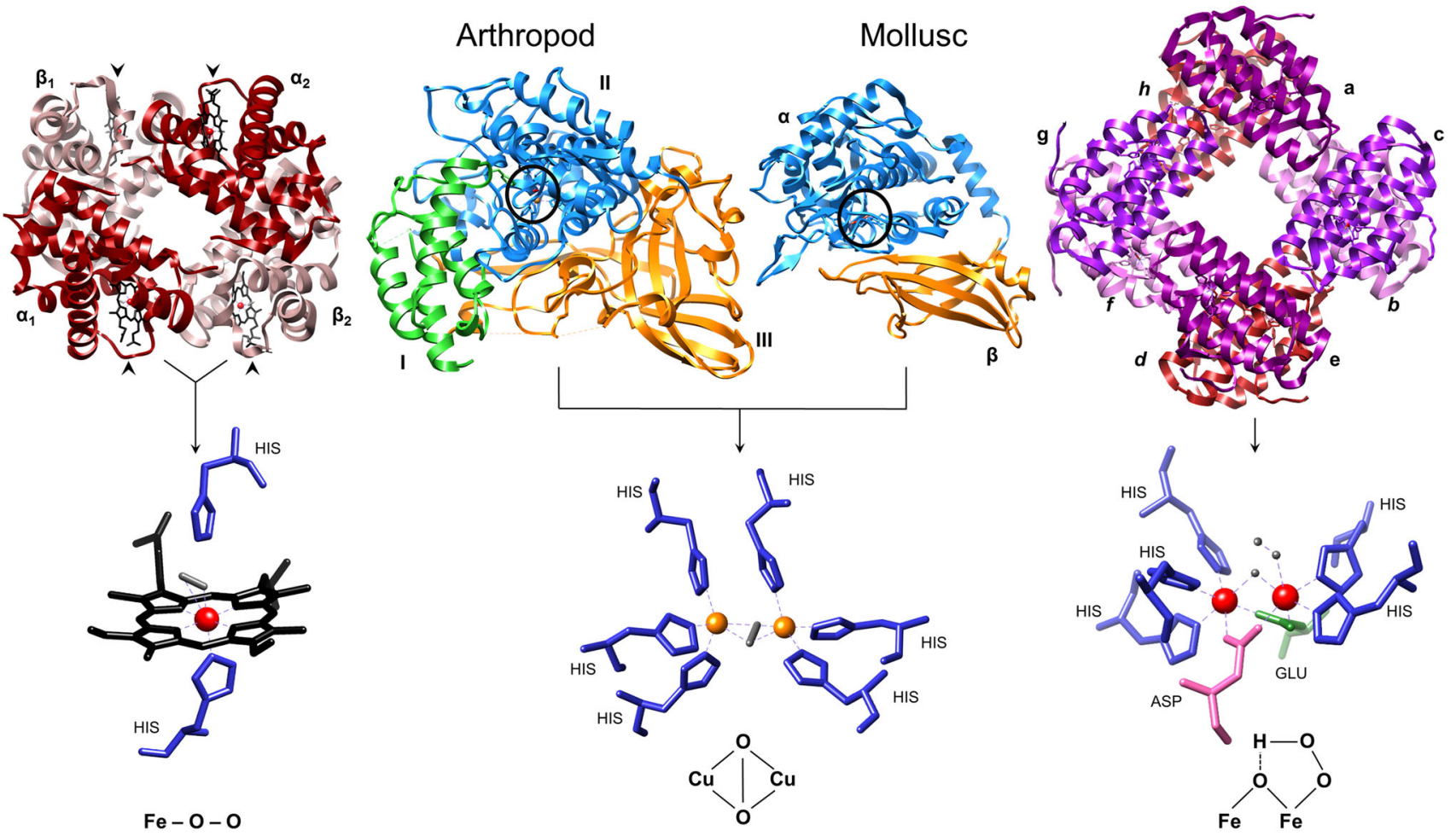

Fig. 1 Three major classes of oxygen-transport proteins. Each of the 4 subunits $(\alpha 1, \alpha 2, \beta 1, \beta 2)$ making up human $\mathrm{Hb}$ (and monomeric myoglobin) contain heme cofactors $\left(\mathrm{Fe}^{2+}\right.$ - protoporphyrin IX) that bind $\mathrm{O}_{2}$. Each heme group is indicated by an arrow head. The proximal histidine forms a direct bond with the iron atom, while the distal histidine is suggested to form a hydrogen bond with $\mathrm{O}_{2}$. The distal His hinders the energetically favoured straight binding of $\mathrm{O}-\mathrm{O}$. Arthropod hemocyanin subunits consist of three domains (green, blue, orange) and mollusc hemocyanin FUs consist of two domains (blue, orange). The blue domains possess two copper atoms, each is coordinated by three highly conserved histidine residues. $\mathrm{O}_{2}$ is bound in a 'side on' $\left(\mu-\eta^{2}: \eta^{2}\right)$ bridging formation between $\mathrm{CuA}$ and $\mathrm{CuB}$.

cases, Hc content has been calculated in excess of $140 \mathrm{mg} \mathrm{mL}^{-1}$ in the chelicerate, Limulus polyphemus $[16,20]$. Accumulating evidence suggests that $\mathrm{Hc}$ is an integral component of biological defence systems within arthropods [reviewed by 21]. Oxygen-carrying Hc can be activated by host (clotting proteins, phospholipids, AMPs, proteases, lipoproteins) and microbial (proteases, membrane ligands) factors to combat infection, parasitism, viremia and physical damages [22-32].

Mollusc Hcs are extremely large protein complexes dissolved in the hemolymph of gastropods and cephalopods $[33,34]$. Typically, subunit molecular masses range from 330 to $450 \mathrm{kDa}$ depending on the species. Subunits are composed of 7 or $8(50 \mathrm{kDa})$ functional units (FU; Fig. 1), designated FU-a to FU-h. Ten of these subunits form a hollow cylinder with a diameter of $\sim 310 \AA$ and a height of $\sim 160 \AA$ A. Decameric Hcs are found in cephalopods such as Nautilus pompilius [35]. Two of these cylinders can
Hemerythrin (and myo-hemerythrin) secure $\mathrm{O}_{2}$ between two iron atoms $\left(\mathrm{Fe}_{1}\right.$ and $\left.\mathrm{Fe}_{2}\right)$ which are held in place by five histidines residues, one aspartic acid and one glutamic acid. In the process, a hydroperoxide $(\mathrm{OOH}-)$ complex is formed. Images were produced using UCSF Chimera [202] and crystal structures from the Protein Data Bank: human hemoglobin tetramer $1 \mathrm{GZX}\left(\alpha_{2} \beta_{2}, \sim 64 \mathrm{kDa}\right)$, arthropod hemocyanin subunit 1OXY $(\sim 72 \mathrm{kDa})$, mollusc hemocyanin functional unit 1JS8 $(\sim 50 \mathrm{kDa})$ and sipunculid hemerythrin homo-octamer 1I4Y ( $\sim 108 \mathrm{kDa})$. Inset oxygen is coloured grey; iron is coloured red; copper is coloured orange; histidines are coloured blue: aspartic acid is pink and glutamic acid is green

associate along the rotational axis to form di-decamers as observed in marine gastropods [33]. The largest known mollusc Hc is a 13.5 MDa tri-decamer discovered in several species of snail, e.g. Melanoides tuberculata and Terebralia palustris [36]. Renewed interests in Hc structural complexities and the assemblages of associated sugars and lipids aim to exploit the vast therapeutic potential of these megamolecules (Table 1). Especially from molluscs, Hcs are tested for application as bio-adjuvants (viral and bacterial antigens/haptens), immune-stimulants for treatment of cancers such as melanoma, and carrier molecules for vaccines (Table 1) [37-40].

\section{Hemerythrins}

Hemerythrins (Hr) are relatively rare, non-heme, di-iron, dioxygen-binding proteins present in specialised coelomocytes (hemerythrocytes) of brachiopods, priapulids, 
Table 1 Recent examples of hemocyanin-based therapeutics

\begin{tabular}{|c|c|c|c|}
\hline Source & Chemical modification & $\begin{array}{l}\text { Adjuvancy, immune-stimulatory } \\
\text { and anti-cancer properties }\end{array}$ & References \\
\hline Blacklip abalone (Haliotis rubra) & Native & Antiviral: herpes simplex virus-1 & [41] \\
\hline $\begin{array}{l}\text { Chilean abalone (Concholepas } \\
\text { concholepas) }\end{array}$ & $\begin{array}{l}\text { Native } \\
\text { Oxidation of carbohydrates using } \\
\text { sodium periodate }\end{array}$ & $\begin{array}{l}\text { B16F10 melanoma model (IFN- } \gamma \\
\text { secretion) } \\
\text { Mouse bladder carcinoma model }\end{array}$ & $\begin{array}{l}{[42]} \\
{[37]}\end{array}$ \\
\hline $\begin{array}{l}\text { Giant Keyhole Limpet (Megathura } \\
\text { crenulata) }\end{array}$ & $\begin{array}{l}\text { Rindopepimut }^{\mathrm{a}} \text { conjugated to KLH } \\
\text { Heptavalent KLH and QS- } 21^{\mathrm{b}} \\
\text { Sialyl-Tn KLH }\end{array}$ & $\begin{array}{l}\text { Glioblastoma multiforme (brain) } \\
\text { Epithelia ovarian, fallopian tube and } \\
\text { peritoneal cancer } \\
\text { Metastatic breast cancer }\end{array}$ & [43-45] \\
\hline Limpet (Fissurella latimarginata) & $\begin{array}{l}\text { Native } \\
\text { Oxidation of carbohydrates using } \\
\text { sodium periodate }\end{array}$ & Melanoma (B16F10 cells) & {$[38]$} \\
\hline Shrimp (Litopenaeus vannamei) & Native & HeLa cells (cervical cancer) & [46] \\
\hline $\begin{array}{l}\text { Snails (Helix aspersa) } \quad \text { (Helix lucorum) } \\
\quad \text { (Helix pomatia) }\end{array}$ & Native & $\begin{array}{l}\text { Bladder cancer cell lines (T-24 and } \\
\text { CAL-29) } \\
\text { Ovarian carcinoma (FraWü) } \\
\text { Acute monocytic leukaemia (THP-1) } \\
\text { Human malignant glioma (LN-18) } \\
\text { Human Burkitt's lymphoma (Daudi) } \\
\text { cell lines } \\
\text { Colon carcinoma (murine model) } \\
\text { Adjuvant for microbial and viral antigens }\end{array}$ & [47-49] \\
\hline Whelk (Rapana thomasiana) & $\begin{array}{l}\text { Choline amino acid salts } \\
\text { Imidazolium-based amino acid ionic } \\
\text { liquids }\end{array}$ & Human breast cancer cells (MCF-7) & {$[39,40]$} \\
\hline
\end{tabular}

${ }^{a}$ Epidermal growth factor-related peptide

b Synthetic saponin adjuvant

sipunculids and annelids [50-53]. Most often viewed as an octamer of molecular mass $\sim 108 \mathrm{kDa}$ (Fig. 1), dimeric, trimeric and tetrameric isoforms of $\mathrm{Hr}$ have also been observed. These homo- or hetero-octamers are made up of $\alpha$ - and $\beta$-type subunits, each $\sim 13-14 \mathrm{kDa}$ in size [54]. Subunits consist of a four- $\alpha$-helix motif that houses the two iron ions, one being hexa-coordinated and the other pentacoordinated (bridged by a hydroxyl ion). Between the hydroxyl group and a single iron ion, oxygen is bound reversibly in an 'end on' position (Fig. 1) [55]. To date, $\mathrm{Hr}$ has not been detected in a deuterostome, whereas many bacteria, fungi and archaea contain Hr-like domains that are seemingly involved in chemotaxis [56]. Muscle-specific hemerythrin (myoHr), which is functionally equivalent to $\mathrm{Mb}$, has been observed in polychaete and sipunculid tissues [57, 58]. Uniquely, the phylum Annelida contains isoforms of all known iron-based OTPs [5, 51].

\section{Hemoglobin and erythrocytes contribute to mammalian innate immunity}

Iron is a precious commodity utilised by microbes for growth and pathogenicity. To colonise and persist in metazoans, microbes must circumvent the many ironwithholding mechanisms of the innate immune response [reviewed by 60]. During infection, hemolytic bacteria (e.g. Staphylococcus aureus and Streptococcus pyogenes) will lyse erythrocytes to exploit the iron stored within. The extra-erythrocytic $\mathrm{Hb}$ is detected and sequestered by the glycoproteins, haptoglobin ( $\mathrm{Hp}$ ) and hemopexin, and the lipid-free apolipoprotein A-I, all of these are freely dissolved in the plasma [60-63]. Binding of $\mathrm{Hp}$ to $\mathrm{Hb}$ restricts access to the iron centre, thereby neutralising Hb's prooxidative potential and avoiding damage to vasculatures [64]. Macrophages recognise the $\mathrm{Hp} / \mathrm{Hb}$ complex via the CD163 receptor and internalise the proteins to prevent further inflammation (Fig. 2) [65]. The parasite Trypanosoma brucei uses a glycoprotein receptor to consume $\mathrm{Hp} / \mathrm{Hb}$ complexes for iron removal and recycling. Humans take advantage of this trypanosome receptor by associating lytic molecules (high-density lipoproteins) with Hp-related proteins; tricking the parasite into ingesting the trypanolytic substance [66].

In severe cases of hemolysis (called hemoglobinemia), the excess concentration of $\mathrm{Hb}$ overwhelms the scavenging responses and can cause potentially fatal blockages in the 


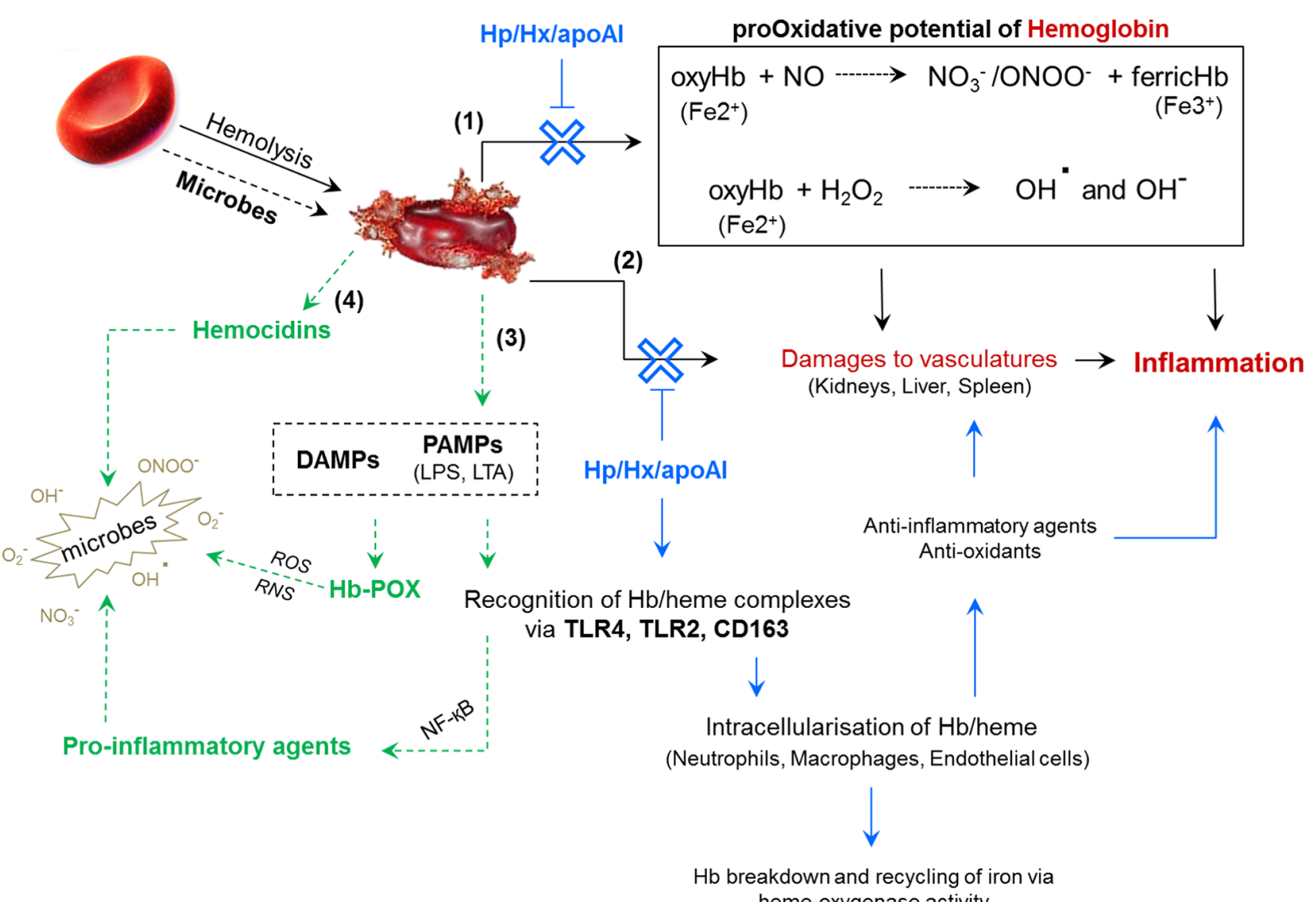

Fig. 2 Schematic representation of hemoglobin functionality beyond oxygen transport. Hemolysis, whether it is caused by microbes or physical trauma, leads to the uncontrolled release of hemoglobins (Hbs). Extracellular $\mathrm{Hb}$ inflicts damages by producing reactive oxygen/nitrogen species (1) and interfering with hepatic, splenic and renal physiologies (2). Inflammation can be avoided/controlled by Hb-scavenging glycoproteins [haptoglobin (Hp), hemopexin $(\mathrm{Hx})$ and apoplipoprotein A-I (apoAI)] and soluble receptors (CD163). These proteins intercept $\mathrm{Hb}$, neutralise its oxidant properties, and direct it towards immune cells for degradation and to promote anti-

kidneys [see review 62]. Extracellular $\mathrm{Hb}$ is a redox-sensitive molecule with the potential to generate reactive oxygen species (ROS) [67]. The ferrous $\left(\mathrm{Fe}^{2+}\right)$ form can convert hydrogen peroxide $\left(\mathrm{H}_{2} \mathrm{O}_{2}\right)$ into hydroxyl radicals $(\mathrm{OH})$ and anions $\left(\mathrm{OH}^{-}\right)$via Fenton's reaction. Such ROS disrupt tissue and cellular integrity via the peroxidation of lipids and the oxidation of nucleic and amino acids [68]. Moreover, plasma oxy-Hb can bind to, and react with, nitric oxide (NO) to produce peroxynitrite $\left(\mathrm{ONOO}^{-}\right)$and ferric $\left(\mathrm{Fe}^{3+}\right)$ oxidised $\mathrm{Hb}$ (methemoglobin) [64, 69, 70] (Fig. 2). NO is an essential antioxidant and plays key roles in immunity, neurotransmission and signalling. In mice and snails (Biomphalaria glabrata), resistance to Schistosoma mansoni is dependent on the production of NO by macrophages and hemocytes, respectively [71, 72]. NO possesses distinct anti-parasitic properties; therefore, the inflammatory responses. Chemical (glutathione) and enzymatic antioxidants (superoxide dismutase, catalase) are recruited also. Anti-infective responses are triggered when $\mathrm{Hb}$ binds to PAMPs/ DAMPs (3). Microbial ligand (PAMPs)-Hb complexes are recognised by immune cells whereupon pro-inflammatory molecules are released, and $\mathrm{Hb}$ is converted into a pseudoperoxidase (POX). If $\mathrm{Hb}$ has been enzymatically processed prior to erythrocyte rupture, then hemocidins (antimicrobial peptides) will also been disseminated (4). This scheme was produced by summarising information presented in the following manuscripts: $[61,62,64,68,80]$

release of $\mathrm{Hb}$ could regulate biological defences targeting Schistosoma and Plasmodium species [73]. The digestion of blood by these hematophagous parasites yields an insoluble, crystalline $\mathrm{Hb}$-derived product called hemozoin [74]. If hemozoin is not removed from circulation by the spleen and liver, it can be phagocytosed by circulating leukocytes. Accumulation of hemozoin in monocytes is said to interfere with key immune molecules such as protein kinase $\mathrm{C}$ and major histocompatibility complex II [75].

Traditionally, pro-inflammatory responses are mediated through the binding of pathogen-associated molecular patterns (PAMPs) by soluble and cell-associated pathogen recognition receptors (PRRs) [76]. PAMPs tend to be extracellular microbial cell wall components (LPS, LTA and $\beta$-glucans) and their degenerated membrane fragments. Cell-free $\mathrm{Hb}$ is categorised as a damage/danger-associated 
molecular pattern (DAMP) because it is perceived as an intracellular-derived indicator of pathological traumas such as malaria, sepsis and sickle-cell anaemia [77]. Not only is the $\mathrm{Hb}$ oligomer/dimer considered a DAMP, but the heme group (protoporphyrin ring) is recognised independently as an 'alarmin' [reviewed by 78]. Proteolytic digestion of extracellular $\mathrm{Hb}$ enhances the dissemination of labile heme within the blood, a physiological indicator of cystic fibrosis [68]. The control and removal of naked heme (hemin) from circulation is addressed by the protein hemopexin [62]. Several studies have noted Hb's ability to interact with microbial ligands (PAMPs), Toll-like receptors (TLRs) and other DAMP molecules (e.g. heat-shock protein HMGB1) [24, 61, 68, 79-81]. Surface plasmon resonance revealed LPS binding sites are present on both the $\alpha$ and $\beta$ globin chains of $\mathrm{Hb}$ [82]. Synthetic peptides representative of these putative ligand-binding regions targeted the lipid A moiety of LPS in vitro, and in doing so, disarmed the endotoxicity. Binding of LPS and/or LTA induces a conformational switch in $\mathrm{Hb}$ that causes the structure to loosen somewhat and enable peroxidase activity [24, 82]. Methemoglobin (metHb) alone and in combination with LTA can be recognised by TLR-2 on the neutrophil plasma membrane [81]. Such interactions enhance neutrophil function, initiating an $\mathrm{NF}-\kappa \mathrm{B}$ signal transduction cascade that culminates in the synthesis of cytokines and other proinflammatory agents. Endothelial cells can also detect extracellular Hb via a TLR-4 pathway [83] (Fig. 2).

Many studies (mentioned above) categorised extracellular $\mathrm{Hb}$ as harmful to the host and should be removed from circulation before noxious radicals are dispersed. Having said that, plasma $\mathrm{Hb}$ is an important warning to white blood cells (WBCs) that homeostasis has been compromised, and recently, Bahl et al. outlined a novel role for $\mathrm{Hb}$ in blood coagulation [84]. Macrophages responded to the presence of cell-free $\mathrm{Hb}$ by triggering the expression of the vertebrate pro-clotting initiator, tissue factor. Binding of $\mathrm{Hb}$ to tissue factor provided it with protection against antioxidants (e.g. glutathione), and reciprocally, the pro-oxidative potential of $\mathrm{Hb}$ was suppressed to mitigate collateral damage to the host's cells. Infection-induced hemolysis and the liberation of $\mathrm{Hb}$ promote downstream pro-inflammatory and proclotting reactions [84] (Fig. 2). Remarkably, Hb gene expression and protein synthesis were recorded in cytokine (IFN $\gamma$ ) and LPS-stimulated murine macrophages [85] and surfactant-producing human alveolar type II epithelial cells [86]. The biological function of $\mathrm{Hb}$ production outside of erythroid tissues remains unclear. It is postulated, however, $\mathrm{Hb}$ may enable these particular cells to cope with nitrosative/oxidative imbalances as macrophages produce excess NO when presented with microbes, and alveolar epithelia are subjected to high levels of $\mathrm{CO}_{2}$ during gas exchange, which may affect cytosolic $\mathrm{pH}$.
Beyond immune cell communication and hemostasis, $\mathrm{Hb}$ participates in host defences by releasing AMPs [87], discharging ROS locally [24], and functioning as a microbiostatic molecule (Table 2). The earliest record of Hb's immune competence was reported over 55 years ago [9]. Hb prepared from human tissue extracts was inhibitory to several enteric bacteria (listed in Table 2), with maximum activity occurring at $37{ }^{\circ} \mathrm{C}$ under acidic conditions $(\mathrm{pH}<5.5)$ and low salt concentrations $(<0.2 \mathrm{M})$. Bovine, equine, murine and rabbit Hbs were similarly antiseptic. $\mathrm{Hb}$ tetramers $(\sim 64 \mathrm{kDa})$ are probably too large to penetrate the bacterial membrane directly. The basic charge of $\mathrm{Hb}$ would promote non-specific electrostatic interactions with the acidic moieties of microbial polysaccharides, proceeding to immobilise the cells and prohibit replication. Two consecutive studies by Mak et al. [88] and Parish et al. [89] provided detailed accounts on the conversion of $\mathrm{Hbs}, \mathrm{Mb}$ and cytochrome $\mathrm{c}$ into antimicrobials. Intact $\mathrm{Hb}$ and $\mathrm{Mb}$ were moderately effective at killing bacteria such as $E$. coli until the removal of the heme cofactors and partial unfolding of the proteins resulted in a broader spectrum of microbicidal properties and $\mathrm{LD}_{50}(\mu \mathrm{M})$ values comparable to conventional AMPs. By treating apomyoglobin and apohemoglobin with cyanogen bromide, the globin chains were deconstructed into AMPs ca. 50 amino acids in length (Table 2; Supp. Table 1; Fig. 3). This family of $\mathrm{Hb}$-derived AMPs was referred to as 'hemocidins' [88]. Prior to the discovery of hemocidins, human $\mathrm{Hb}$ was already known to be a rich source of over 150 regulatory peptides, e.g. hemorphins with opioid-like tendencies [90]. In fact, the first Hb-derived AMP was removed from the gut of the cattle tick Rhipicephalus (Boophilus) microplus [91]. This $3.2 \mathrm{kDa}$ AMP was identical to residues 33-61 (FLSFPTTKTYFPH-FDL SHGSAQVKGHGAK) of bovine $\alpha-H b$ (Supp. Figure 1), and targeted Gram-positive bacteria, filamentous fungi and yeast [91]. A second tick species, Ornithodoros moubata, contained two anti-Staphylococcal peptides in its midgut after a blood meal [92]. Edman degradation verified the origin of these peptides to be overlapping fragments (residues $1-11$; 3-19) from rabbit $\alpha \mathrm{Hb}$. When in solution, the bovine peptides Hb33-61 and Hb1-23 do not form distinct secondary structures, i.e. they are unfolded. Upon insertion of Hb33-61 into anionic detergent micelles, the cationic peptide establishes an $\mathrm{N}$-terminal $\beta$-turn and a C-terminal $\alpha$-helical arrangement [93]. A flexible region, Pro44-Leu48, forms between the two structural motifs and may act like a hinge to help the peptide penetrate/rupture the lipid bilayers of microbes.

To date, natural sources of human hemocidins include, but may not be limited to, placental tissue, erythrocytes and menstrual vaginal secretions [87]. Liepke et al. observed two AMPs from placental tissue, one from $\gamma-\mathrm{Hb}(130-146)$ 


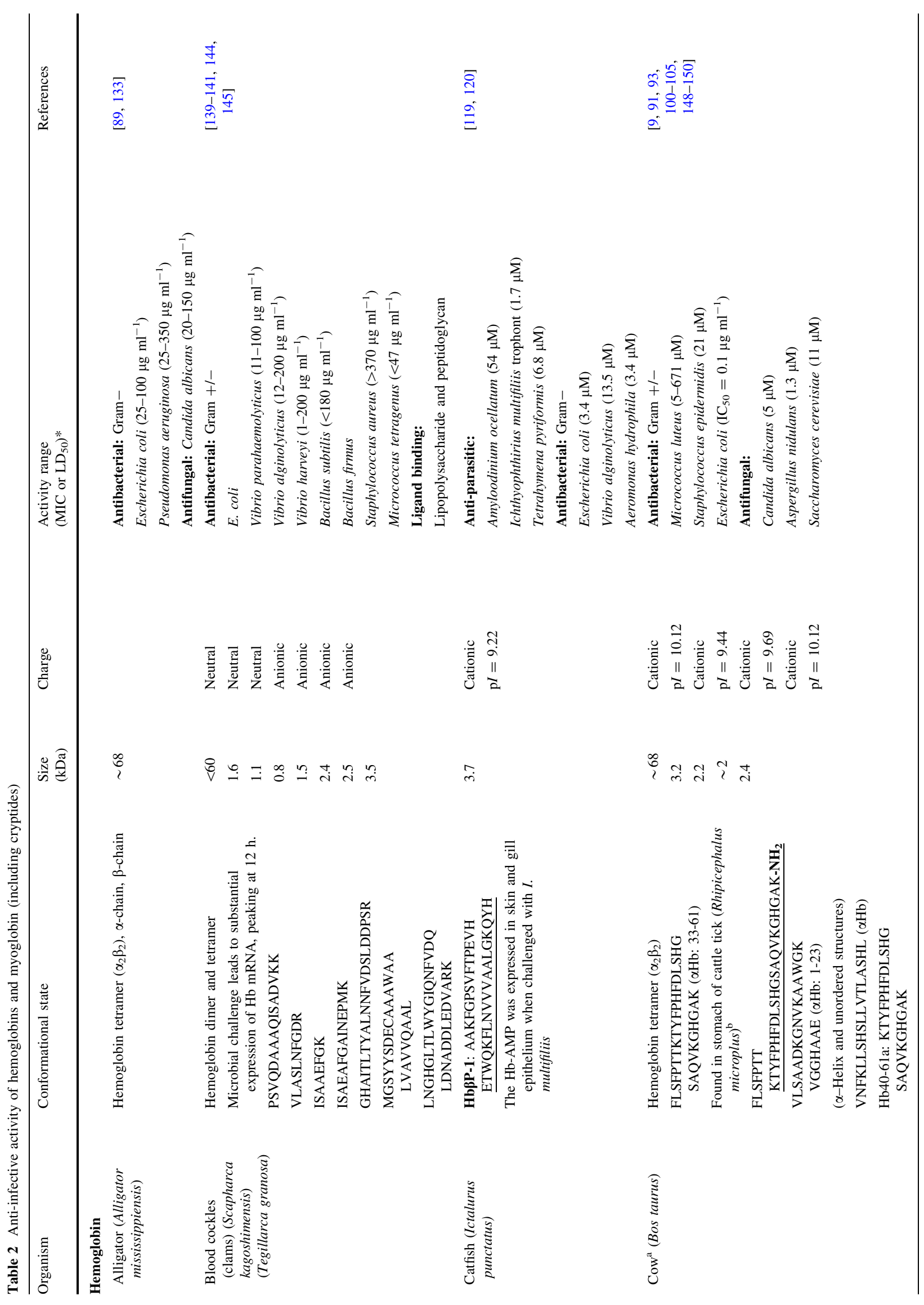




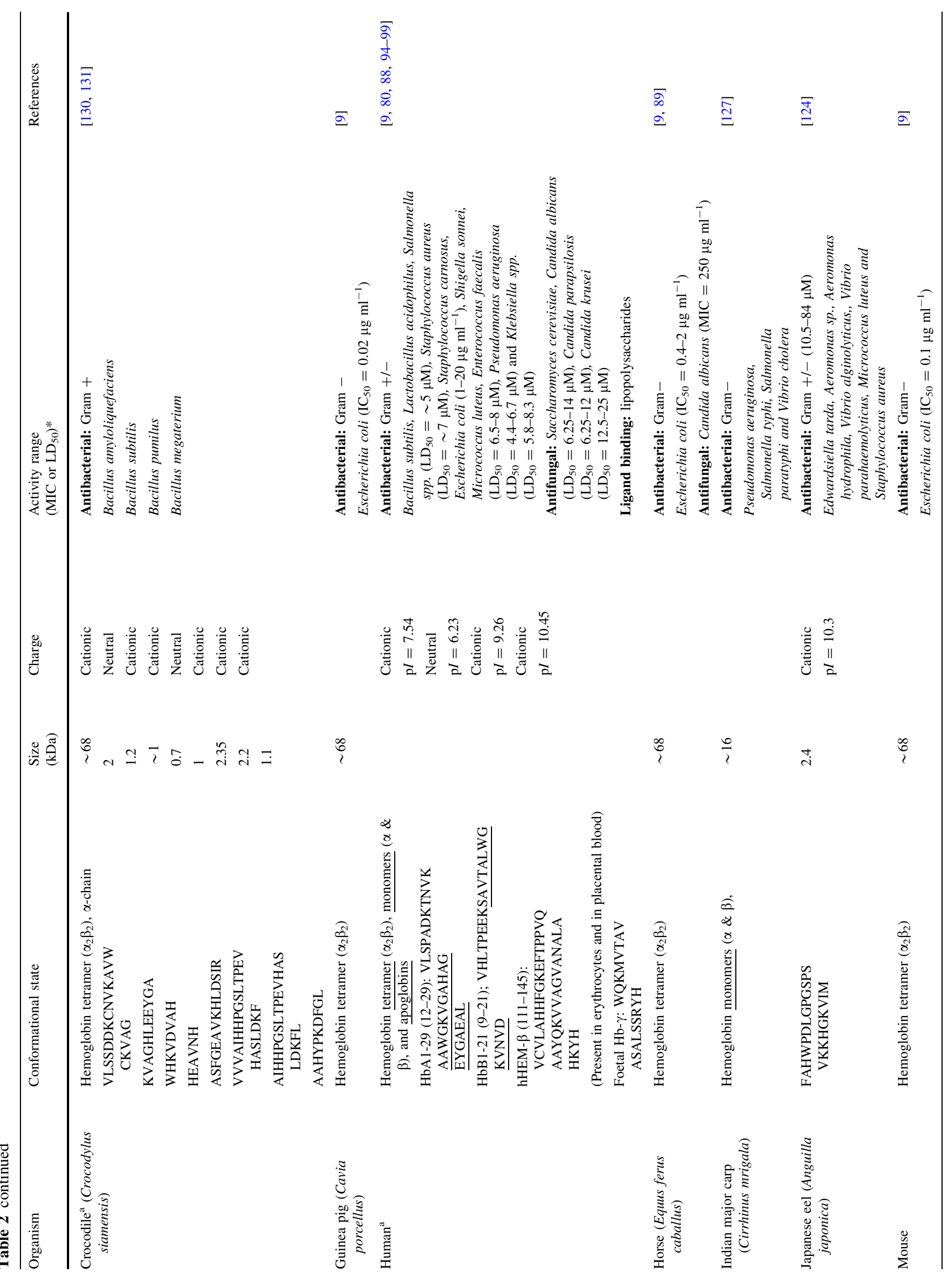




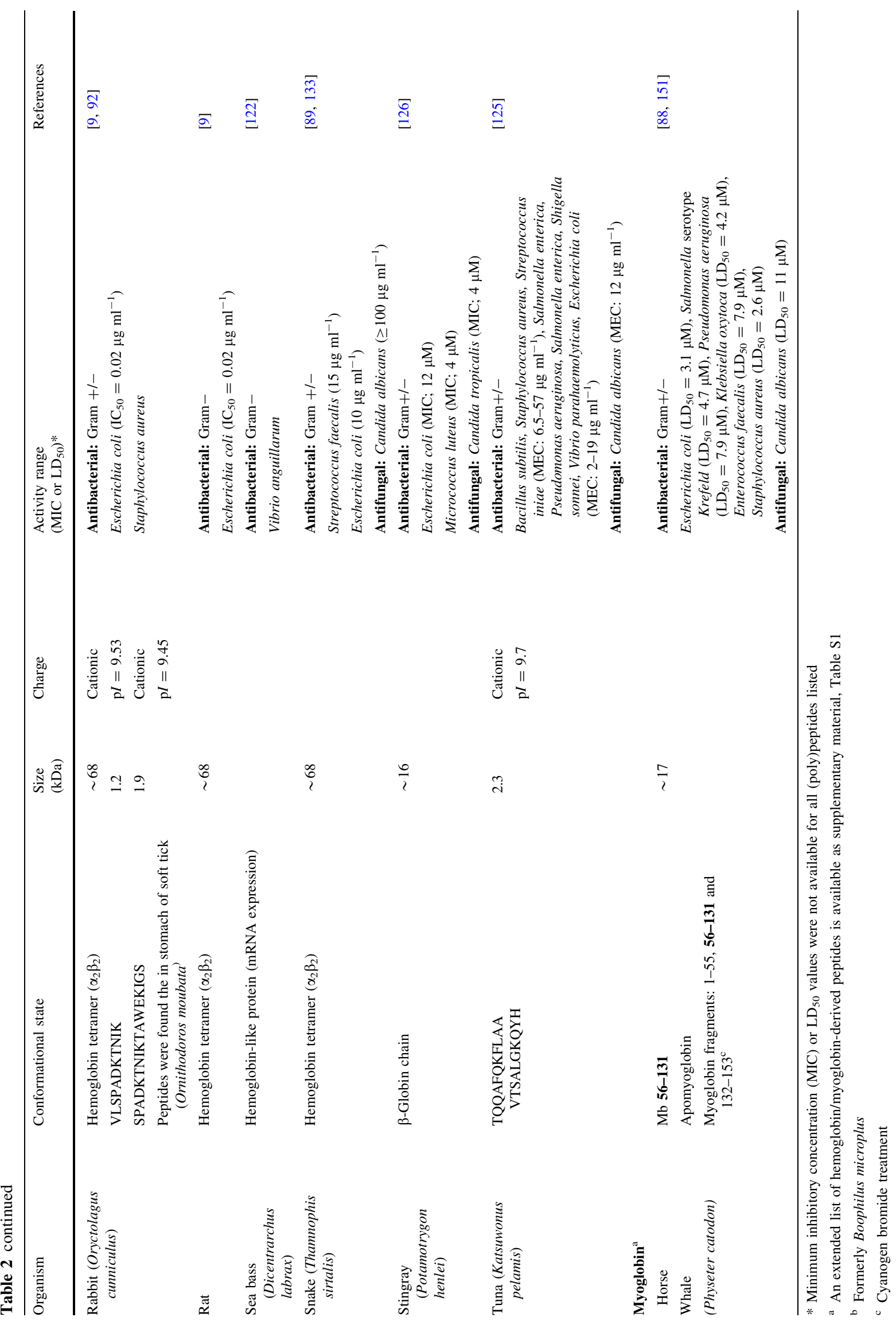




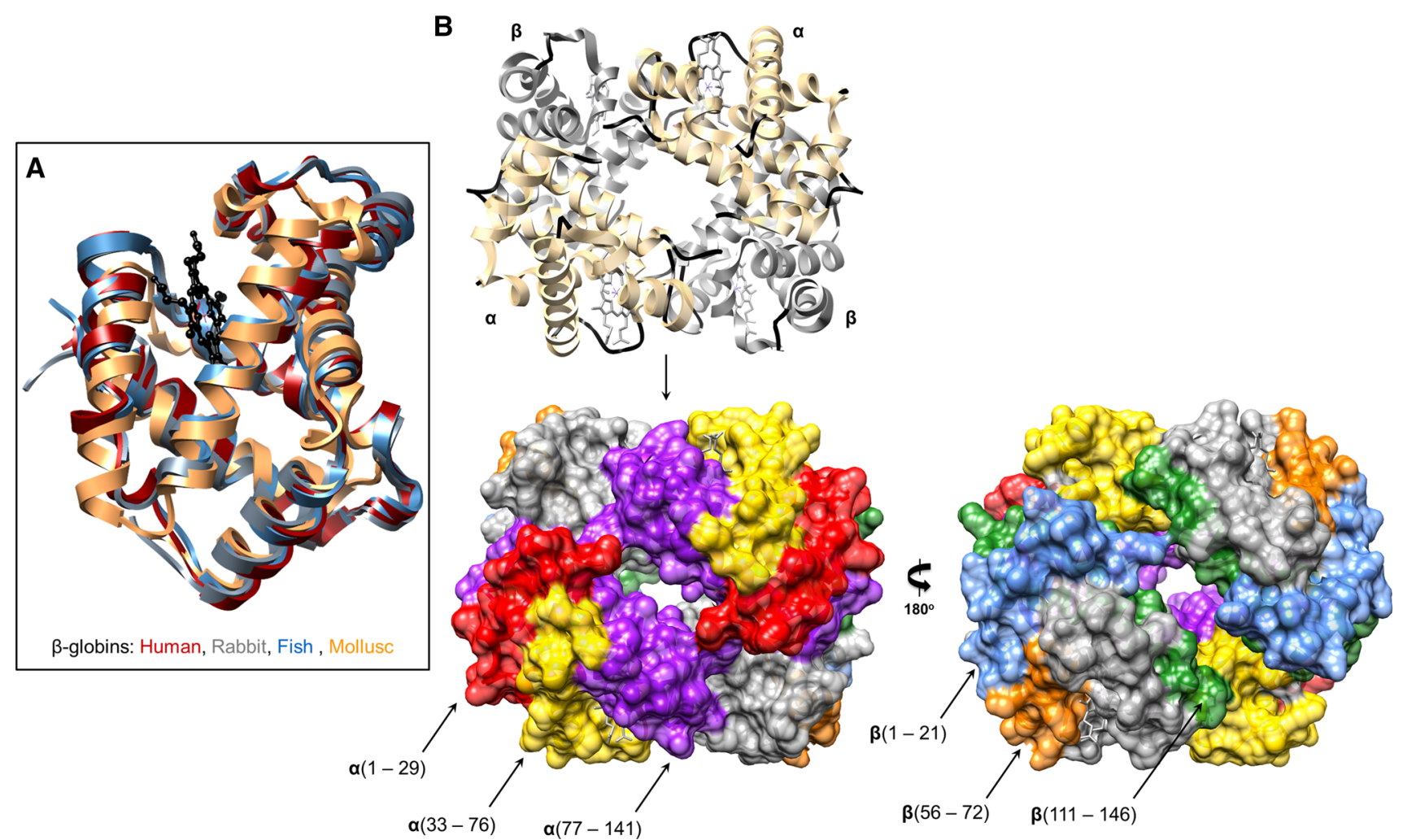

Fig. 3 Hemoglobins and the locations of hemocidins. a Human (PDB 1GZX red), rabbit (PDB 2RAO grey), fish (PDB 3BJ2 blue) and mollusc (PDB 4HRR brown) $\beta$-globin structures have been aligned and superimposed to highlight the conserved helical structures. The protoporphyrin ring is coloured black. B Secondary structural features of the oxy-hemoglobin tetramer (PDB 1GZX) are presented as ribbons. Alpha and beta chains are coloured light yellow and grey, respectively. Coils are coloured black. The space-filling models of $\mathrm{Hb}$

and a second from $\beta-\mathrm{Hb}(111-146)$. The latter $\beta \mathrm{Hb}$ peptide was present in large amounts, $\sim 360 \mathrm{mg} \mathrm{kg}^{-1}$ tissue, preprocessed from the $\mathrm{Hb}$ tetramer within the cytosol of erythrocytes, and could bind to endotoxins [94]. The most convincing evidence for hemocidins functioning in vivo comes from vaginal blood [95-99]. Initial screenings identified 44 hemocidins, most of them originating from the $\mathrm{N}$-terminus of $\alpha \mathrm{Hb}$. Two synthetic peptides, $\mathrm{Hb} \alpha$ 35-56 and $\mathrm{Hb} / 115-146$, identical to natural peptides purified previously showed preferential activity towards Gramnegative bacteria, less activity toward Gram-positives, and no effect on fungal growth/reproduction [95]. Hb $\beta 115-146$ is an acidophilic, halo-tolerant peptide that potentiates the microbicidal effects of common neutrophil-derived immune effectors such as $\alpha / \beta$-defensins and lysozyme, which are found in the female urogenital tract [97]. Hemocidins present in the vagina act as bacterial deterrents and assist immune defences during times of intense physiological strain, such as menstruation and childbirth [87, 96]. It remains unclear how hemocidins are formed and deposited into the vagina. The acidic $\mathrm{pH}$ may denature were used to highlight the location of various antimicrobial peptides (black arrows). The $\alpha$-chain peptides consist of residues 1-29 (red), 12-29 (red), 33-76 (yellow) and 77-141 (purple). The $\beta$-chain peptides consist of residues 1-21 (blue), 9-21(blue), 56-72 (orange) and 111-146 (green). It is worth noting that the $\mathrm{Hb}-\beta$ peptide 111-146 was detected in the placenta and in the cytosol of erythrocytes [94]

the $\mathrm{Hb}$ oligomers enough to allow endo/exo-peptidases and neutrophil-derived matrix metalloproteases to separate the peptides in a step-wise manner.

The laboratory of J.L. Ding in Singapore has provided unequivocal evidence to support a role for $\mathrm{Hb}$ in innate immunity. Damage to, and lysis of erythrocytes, by hemolytic bacteria guides the release of pro-oxidative $\mathrm{Hb}$ into the surrounding milieu. The more virulent pathogens continue to secrete proteases for digesting $\mathrm{Hb}$. Microbial ligands and proteases act in synergy and amplify the pseudoperoxidase (POX) activity of $\mathrm{Hb}$. Concurrently, the pathogen is bombarded with a battery of 'dual-active' $\mathrm{Hb}$ congeners/peptides that bind to exoplasmic membrane structures and inflict localised cytotoxic radicals to weaken/kill the pathogen in situ [24, 80, 82]. Hb-PAMP aggregates are inflammatory agonists (mentioned above), stimulating the expression of cytokines before being recycled by proteasomes and heme-oxygenase within circulating phagocytes (Fig. 2).

Functionally versatile hemocidins have been retrieved from endogenous sources (erythrocytes, ticks, uterine 
secretions) and by in vitro chemical/enzymatic manipulation (e.g. amidation) of commercially sourced globins (listed in Table 2; Supp. Table 1). Synthetic analogues of bovine and human $\mathrm{Hb}$ peptides are now screened routinely for therapeutic potential, e.g. anti-HIV-1 [94, 100-106]. Peptide release from larger 'maternal' proteins is more widespread than once thought. Indeed, the 'cryptome' refers to the entire subset of proteins/peptides released from maternal sources, which have alternative or heightened activities [107-109]. Human lactoferrin [110, 111], lysozyme [112] and cathepsin G [113] are more examples of macromolecules containing encrypted peptides.

\section{Use of hemoglobin by microbes}

Certain pathogens adapted for intracellular life enlist their own heme containing globins to combat the harsh internal environment of leukocytes. A truncated $\mathrm{Hb}$ produced by Mycobacterium tuberculosis $(\mathrm{HbN})$ is necessary for infectivity [114]. The microbe-derived $\mathrm{HbN}$ decomposes NO produced by macrophages and neutrophils so the bacterium may survive within the cytosol. $\mathrm{HbN}$ acts as a NO dioxygenase despite the absence of a true reductase domain [115]. HbN expression intensifies once the bacterium enters the WBC. Subsequently, the protein is glycosylated post-translationally and localised to the cell membrane/wall. The expression of CD80/86 co-stimulatory surface receptors on the phagocyte cell surface is suppressed during $M$. tuberculosis occupancy, linked to an increase in $\mathrm{HbN}$ concentration [114]. It appears that $\mathrm{HbN}$ not only protects the bacterium from the cytosolic defences of WBCs, but also modulates the expression of host immune factors.

The causative agent of thrush, Candida albicans, secretes up to ten acid hydrolases (aspartic peptidases) when attempting to colonise the vagina. These enzymes attack the host's defences, and are capable of using the existing $\mathrm{Hb}$ as a substrate for peptide production. These $\mathrm{Hb}$ hydrolysates are effective bactericidals, especially in the presence of Lactobacillus acidophilus [99]. Intriguingly, these observations imply that $C$. albicans exploits human $\mathrm{Hb}$ to antagonise bacteria and reduce competition within the vagina.

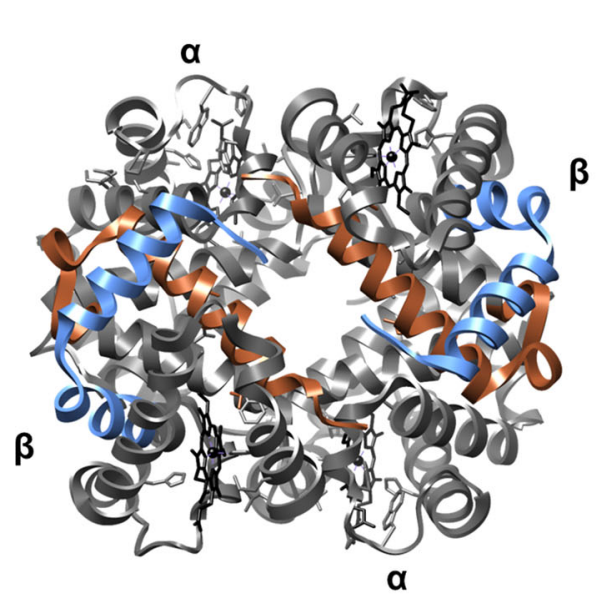

Fish hemoglobin

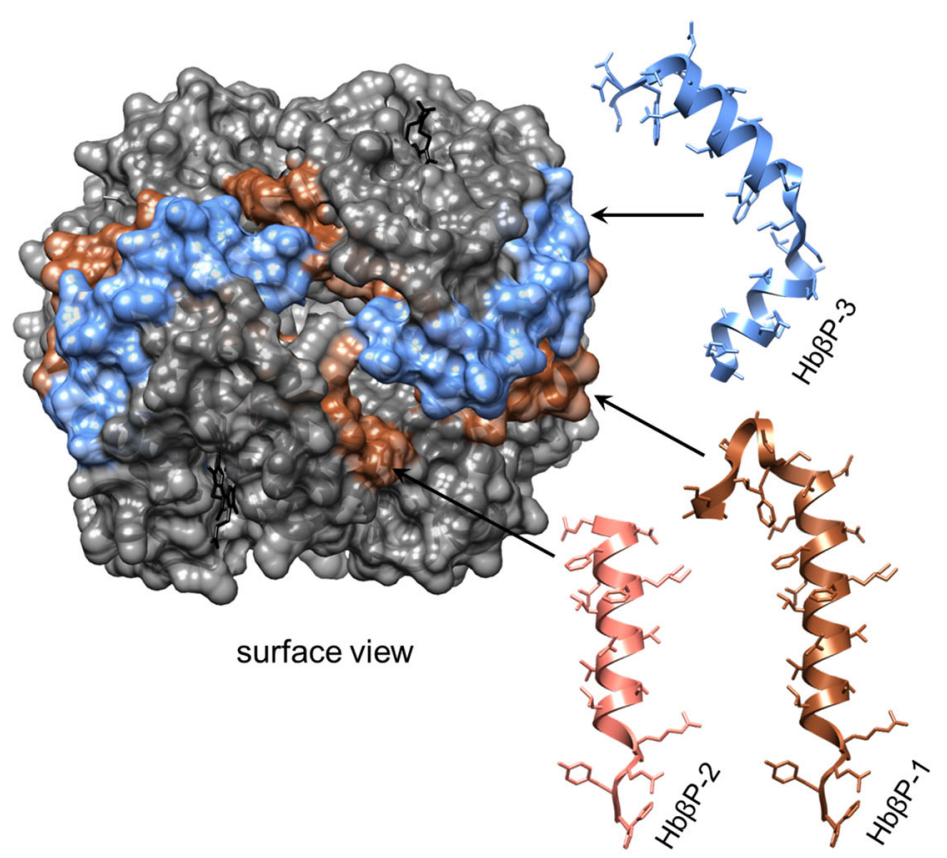

surface view
Fig. 4 Hemoglobin-derived antimicrobial peptides from fish. The overlapping encrypted peptides (Hb $\beta \mathrm{P}-1,2$ and 3) of fish (Ictalurus punctatus; GI:318171215) hemoglobin are presented using the crystal structure of rainbow trout hemoglobin (3BOM). The helical structures of each peptide are presented as ribbons, and their locations are indicated by black arrows. It has not been confirmed whether the peptides retain these structural features upon detachment from the $\mathrm{Hb}$ 


\section{Fish hemoglobin and erythrocytes}

Functional plasticity of erythrocytes from non-mammalian vertebrates such as trout (Oncorhynchus mykiss) and chickens has been confirmed in vitro [116]. Aside from links to reproductive and endocrine physiologies, these nucleated erythrocytes employ common PRRs (e.g. TLR 3) to detect PAMPs (LPS, PGN) and respond by synthesising a plethora of immune-related mRNAs (chemokine CCL4, IFN $\alpha$ ). These erythrocytes are further capable of communicating the presence of viral mimics (polyinosinic: polycytidylic acid) to macrophages via a type-1 IFN response [116]. Erythrocyte-pathogen antibiosis is frequently encountered across the literature, yet critically, there is now sufficient evidence for erythrocyte-specific roles in fish, reptile and bird innate immunity [reviewed by 117]. First, in 2004, antibacterial proteins were recovered from ruptured erythrocytes of rainbow trout [118]. These cationic proteins targeted Planococcus citreus and E. coli with MIC values in the sub-micromolar range. Although the authors did not purify individual compounds, they speculated (based on size) that histone H2A was involved. It is highly likely some $\mathrm{Hb}$ found its way into the final protein extract, regardless of the 'harsh' extraction procedure used and the loss of $\mathrm{Hb}$ via precipitation [118]. Lately, piscine $\mathrm{Hb}$ subunit chains $(\alpha \& \beta)$ and peptides of various sizes have been reported acting in an anti-infective manner (listed in Table 2).

In catfish (Ictalurus punctatus) infected with the ciliate parasite ich (Ichthyophthirius multifiliis), variants of the $\beta$ $\mathrm{Hb}$ gene were transcribed and translated in epithelial surfaces of the skin and gills, as well as in erythrocytes [119]. In total, three cationic $\mathrm{Hb}$-derived peptides were identified, $\mathrm{Hb} \beta \mathrm{P}-1$ to $\mathrm{Hb} \beta \mathrm{P}-3$. These peptides emerged from both the $\mathrm{C}$ - and $\mathrm{N}$-termini of the $\beta$-globin monomer (Fig. 4). The extra-erythrocytic peptide, $\mathrm{Hb} \beta \mathrm{P}-1$ (3.7 kDa), was lethal to eukaryotic and prokaryotic fish ectoparasites: Amyloodinium ocellatum, I. multifiliis and Tetrahymena pyriformis $[119,120]$. In vivo concentrations of $\mathrm{Hb} \beta \mathrm{P}-1$ increased under immune challenge and were selectively toxic to the trophont stage of the parasites. Unlike many of the human hemocidins discussed previously, antimicrobial properties of $\mathrm{Hb} \beta \mathrm{P}-1$ were limited to a few Gram-negative bacterial pathogens (Table 2).

Significant increases in $\mathrm{Hb}$ mRNAs were detected in several tissues (gill, skin and spleen) of European sea bass, Dicentrarchus labrax, resulting from exposure to acute physical stress (crowding) and pathogenic challenge (Vibrio anguillarum) [121, 122]. This study mirrored patterns of Hc up-regulation in the hepatopancreas of shrimp ( $L$. vannamei) subjected to microbial and thermal stresses $[21,123]$. The first fish $\alpha$-Hb peptide was extracted from the liver of Japanese eel (Anguilla japonica [124]), and following that, a $\beta-\mathrm{Hb}$ peptide was removed from the liver of Tuna (Katsuwonus pelamis [125]). Peptides from each fish were $<2.5 \mathrm{kDa}$ in size, positively charged and composed of $\alpha$-helices. Antimicrobial activity of the tuna $\mathrm{Hb}$ peptide (SH $\beta A P$ ) was heat stable and $\mathrm{pH}$ resistant, but was non-functional in the presence of chymotrypsin and trypsin [125]. C-terminal amidation of SHBAP enhanced its activity, perhaps by altering the electrostatic interactions with the anionic bacterial membranes. Generally, posttranslational modification of peptides increases their metabolic stability against endogenous peptidases.

The biomolecular composition of stingray (Potamotrygon henlei) mucus was interrogated for the presence of antimicrobials, wherein a $\beta$-Hb polypeptide $(\sim 16 \mathrm{kDa})$ was classified [126]. In vitro assays revealed non-specific microbicidal actions of this $\beta$-Hb monomer in the presence of bacterial and fungal targets (Table 2). The stingray $\mathrm{Hb}$ did not show any adverse cytotoxicity upon exposure to mammalian cells, and injection of the protein $(10 \mu \mathrm{M})$ into the cremaster venule of mice induced an ephemeral response in leukocyte rolling behaviour (visualised using intravital microscopy). These data suggest $\beta-\mathrm{Hb}$ is a putative immune bioactive from stingray mucus and has potential therapeutic applications in humans. The Indian major carp, Cirrhinus mrigala, also contains biologically active $\alpha-$ and $\beta-\mathrm{Hb}$ chains in skin mucus, as well as histones $\mathrm{H} 2 \mathrm{~A}, \mathrm{H} 3$ and $\mathrm{H} 4$ [127]. The immune activity of $\mathrm{Hbs}$ in fish mucus and skin epithelia serves as a first-line defence against parasites and pathogens.

\section{Reptile hemoglobin}

Despite crocodiles spending most of their lives in dirty, microbiologically hazardous waters, they show few signs of severe infection even when seriously wounded $[128,129]$. This resistance is due, in part, to the multifunctionality of $\mathrm{Hb}$. Irrespective of the presence or absence of the heme prosthetic group, crocodile (Crocodylus siamensis $) \mathrm{Hb}$ tetramers, various degenerated fragments $(<21$ amino acids), individual globin units ( $\alpha$ and $\beta$ ), and synthetic $\alpha-\mathrm{Hb}$ monomers were all capable of killing Grampositive bacteria (four species of Bacilli) but appeared ineffective against Gram-negative bacteria $(E$. coli) [130, 131]. Electron micrographs taken of B. subtilis [ATCC 6633] cultured in the presence of purified $\mathrm{Hb}$ fractions depicted cell membrane irregularities within $2 \mathrm{~h}$. Many of these crocodile hemocidins share typical features of AMPs: net-positive charge, $>30 \%$ hydrophobic content and their predicted secondary structural motifs are dominated by $\alpha$-helices (Table 2; Table S1). The latter is not entirely surprising considering the conserved helical arrangement of all known Hbs (Fig. 3). Crocodile $\mathrm{Hb}$ is a potent scavenger of oxygenic radicals in vitro, albeit the 
significance of this antioxidant role in vivo has yet to be explored [132].

The antimicrobial features of ectotherm $\mathrm{Hbs}$ are not restricted to Gram-positive bacteria, as snake (Thamnophis sirtalis) and alligator (Alligator mississippiensis) Hbs can inhibit the growth of E. coli, Pseudomonas aeruginosa and the pathogenic yeast, $C$. albicans [89, 133] (Table 2). Alligator $\mathrm{Hb}$ failed to suppress Gram-positive bacteria, Streptococcus faecalis and S. aureus, using a disc diffusion approach [89]. The potency of alligator Hb differs between each globin subunit, e.g. up to fivefold less $\alpha \mathrm{Hb}$ $\left(\mathrm{MIC}=30 \mu \mathrm{g} \mathrm{mL}^{-1}\right.$ ) was needed to inhibit yeast compared to $\beta \mathrm{Hb}\left(\mathrm{MIC}=150 \mu \mathrm{g} \mathrm{mL}^{-1}\right)$ [133].

\section{An emerging role for invertebrate (bivalve) hemoglobin in innate immunity}

Almost all cephalopods and gastropods utilise Hc to dispense dioxygen to metabolically active tissues; an exception being freshwater snails. Species such as the planorbid snail, Biomphalaria glabrata, use giant extracellular Hbs (1.44 MDa) to meet their respiratory needs in what is considered to be an evolutionary abandonment of Hc $[134,135]$. In blue-blooded $(\mathrm{Cu})$ and red-blooded $(\mathrm{Fe})$ snails, $\mathrm{Hc}$ and $\mathrm{Hb}$ are synthesised inside specialist rhogocytes (pore cells) and then released into the plasma $[136,137]$. Bivalves lack Hc, instead they utilise cellbound $\mathrm{Hbs}$ which are structurally similar to vertebrate $\mathrm{Hbs}$ [5, 138]. Analogous to fish and reptiles, bivalves store their $\mathrm{Hb}$ within nucleated erythroid-like cells. Trematode infestation of the Sydney cockle, Anadara trapezia, induced measureable increases in circulating erythrocyte numbers, over double compared to non-parasitised animals [138]. These data add support to earlier findings demonstrating the immune competence of erythrocytes [117].

The cDNA (748 bp) of an intracellular homo-dimeric $\mathrm{HbI}(\sim 31 \mathrm{kDa})$ from the blood clam Tegillarca granosa was cloned and sequenced to reveal $\sim 82 \%$ similarity with Hbs from Scapharca kagoshimensis and Scapharca inaequivalvis [139]. Messenger RNAs of HbI were expressed constitutively in the hemocytes, adductor muscle, foot, gills, gastrointestinal tract and mantle. When clams were injected with LPS, Vibrio parahaemolyticus and/or PGN, HbI mRNA transcript numbers increased significantly. The highest levels of expression were detected in the hemocytes, with an 800-fold increase at $12 \mathrm{~h}$ post-infection (h.p.i.) compared to the control groups. Differential temporal expression patterns of $T$. granosa HbII-A and -B genes in hemocytes were also detected in the presence of microbial ligands (LPS and PGN) and intact bacteria [140, 141]. Over 20 individual nucleotide polymorphisms have been identified across all three $T$. granosa $\mathrm{Hb}$ genes
[141]. Polymorphic loci at exon2-146 (serine to proline switch) and exon2-23 (alanine to threonine switch) on HbII-A and HbII-B, respectively, were recovered from clams having survived heavy $V$. parahaemolyticus loads. These amino acid substitutions likely confer alternate functionality to newly synthesised Hbs. Similarly, $13 \mathrm{Hc}$ associated SNPs have been identified in shrimp (L. vannamei) infected with the same pathogens [142, 143]. These molecular alterations were located in the immunoglobulinlike domain and C-terminal region of the shrimp $\mathrm{Hc}$ resulting in improved microbial agglutination properties.

Positive microbicidal activities of intact $T$. granosa $\mathrm{HbI}$ and HbII were observed in the presence of $E$. coli and several Gram-positive bacteria. Seven $\mathrm{Hb}$-derived peptides ranging in size from 0.8 to $3.5 \mathrm{kDa}$ (Table 2) were effective against Gram-negative bacteria only, verified using live/dead cellular staining [144]. These bivalve hemocidins were removed from the $\mathrm{Hb}$ protomers via trypsin digestion and purified to homogeneity. The aquatic pathogen, Vibrio harveyi, was particularly sensitive to the neutral $\mathrm{Hb}$ peptide 1 (PSVQDAAAAQISADVKK), with an MIC value of $1 \mu \mathrm{g} \mathrm{mL}^{-1}$. Each Hb-derived peptide demonstrated antibacterial potential (Table 2). Additionally, Hb oligomers from $S$. kagoshimensis proved efficient at killing Gram-positive bacteria, yet had no measureable effect on fungal moulds (Aspergillus niger, Penicillium glaucum) or any Gram-negative bacteria tested [145]. The authors of these studies considered ROS production by peroxidase and PO-like activities of $\mathrm{Hb}$ were likely contributing factors to the antimicrobial mechanism. The use of POs to produce ROS and melanins is a conserved defence strategy amongst flora and fauna. PO activities of bivalve hemocytes and proPO within the haemolymph have received much attention [146, 147]. Conversely, studies focussing on $\mathrm{Hb}$-derived PO activities are relatively unheard-of (discussed below).

\section{Inducible phenoloxidase and (pseudo)peroxidase activities of hemocyanins and hemoglobins}

Both arthropod and mollusc Hcs can be converted into POlike enzymes upon physical disruption of the structural motifs in and around the dicopper centres. It is most important to open the entrance to the active site, yet such invasive structural alterations will eventually destroy the PO activity. Either through proteolysis or interactions with endogenous cofactors, placeholder residues (usually with aliphatic or aromatic chemistry) occluding the active sites are dislodged, thus permitting phenolic compounds to be processed into melanin precursors [21, 152]. The POs play vital roles in invertebrate development and contribute to counter-measures targeted towards infectious agents, e.g. 
hemocyte encapsulation/nodulation and using toxic quinones to kill pathogens [153]. POs (tyrosinases [EC 1.14.18.] and catecholoxidases [EC 1.10.3.1]) and Hc-d POs catalyse the ortho-hydroxylation of monophenols $\left(_{L^{-}}\right.$ tyrosine) into diphenols and subsequently oxidise the $o$ diphenols ( $\mathrm{L}_{\mathrm{L}}$-dihydroxphenylalanine) into quinones (dopachrome) [154-157]. Arthropod Hc-d PO can convert 5,6dihydroxyindole directly into melanin, a very resistant polymer net which invaders cannot penetrate [158]. Not all Hcs or POs can carry out the hydroxylation step. Recent data imply that an asparagine residue and a glutamate residue located near the $\mathrm{CuB}$ binding site are essential for tyrosinase activity. These residues fix a conserved water molecule and lower its $\mathrm{pK}$ value to disrupt the hydrogen from the monophenols (i.e. deprotonate), so the resulting phenolate can bind to $\mathrm{CuA}$ to initiate the enzymatic cycle [159-161]. The proton will be bound by this water molecule to form a hydronium ion $\left(\mathrm{H}_{3} \mathrm{O}^{+}\right)$. After release of the final product, namely o-quinone, a hydroxyl group bridges the two copper ions but will be discarded as a water molecule after obtaining a hydrogen back from the hydronium ion. Upon replacing either the asparagine or glutamine residues with different amino acids only catecholoxidase activity is possible [161]. In the absence of a true PO, chelicerates rely on the inducible PO activity of Hc as a substitute [28, 30, 162, 163, 203, 204]. Lately, Hc was found to be a major component of clots formed during hemostasis in the spider, Acanthoscurria geniculata. It is postulated that Hc, like PO, enables protein cross-linking and sclerotisation of the cuticle post-moulting [32]. These findings are supported by earlier studies where Hc was present in abundance throughout the cuticles of shrimp (Penaeus japonicus) and tarantula (Eurypelma californicum) exoskeletons [164, 165].

Both mono-dimeric $(31.2 \mathrm{kDa})$ and hetero-tetrameric ( $\sim 60 \mathrm{kDa})$ conformational states of blood clam ( $S$. kagoshimensis) $\mathrm{Hb}$ were found to possess PO-like activity. In vitro, $\mathrm{Hbs}$ could oxidise diphenols (catechol and $\mathrm{L}^{-}$ DOPA; Table 3) to quinones (dopachrome) but were unable to carry out the initial hydroxylation reaction on monophenols [145]. Catalytic turnover was enhanced $\sim 20 \%$ by the polar solvent isopropanol, although exposure to SDS and trypsin led to a $75 \%$ reduction in activity. SDS and ionic liquids are known to induce transient activity in many enzymes, including POs and Hc-d POs [155, 166, 167]. Bivalve $\mathrm{Hb}$ may be particularly sensitive to SDS-driven denaturation and tryptic digestion. Thermal and $\mathrm{pH}$ ranges of $\mathrm{Hb}-\mathrm{d} \mathrm{PO}$ as well as kinetic parameters such as substrate binding efficiencies $\left(K_{\mathrm{m}}\right)$ for catechol and L-DOPA are similar to arthropod and mollusc Hc-d POs, notably cuttlefish (Sepia officinalis), snails (Helix pomatia) and crabs (Charybdis japonicus) (Table 3) [144, 145, 168-170]. Hb-d PO activity can be inhibited by known tyrosinase inhibitors (e.g.1-phenyl, 2-thiourea), standard metal chelators (EDTA, DETC) and antioxidants (ascorbic acid) in a similar way to POs [145]. The question remains, however, is $\mathrm{Hb}$ a latent $\mathrm{PO}$ or simply able to oxidise phenols non-specifically due to the presence of a transient metal ion within the heme cofactor?

In 2007, a seminal paper published by Jiang and coworkers described the pseudoperoxidase activity of human metHb and the PO activity of horseshoe crab $\mathrm{Hc}$ in the presence of extracellular proteases released by bacteria and fungi [24]. Hb and Hc were 'switched on' upon binding to bacterial ligands, LPS (Gram-) and LTA (Gram+), but were unaffected by laminarin. The generation of superoxide anions $\left(\mathrm{O}_{2}{ }^{-}\right)$by metHb correlated positively with concentrations of microbial stimulants, and equally, was suppressed by the addition of superoxide dismutase. Furthermore, increases in metHb ROS production were recorded inside erythrocytes exposed to different strains of $S$. aureus, highlighting the significance of this activity in vivo [24]. The peroxidase potential of $\mathrm{Hb}$ appears to be conserved amongst metazoans. Clam $\mathrm{Hb}$ can oxidise guaiacol (a methylated derivative of catechol) in the presence of $\mathrm{H}_{2} \mathrm{O}_{2}$ [144]. The catalytic turnover of phenols into quinones, whether it is by $\mathrm{Hc}, \mathrm{PO}$ or $\mathrm{Hb}$, generates volatile by-products [21, 24, 144, 145]. These oxidase-related enzymatic by-products boast significant broad-spectrum antimicrobial properties [171] evidenced by mollusc Hb's inability to kill microbes in the presence of the ion scavenger, glutathione [144]. ROS formation by OTPs arises independently of immune signalling cascades and, therefore, provides an instantaneous assault on pathogens.

\section{Hemocyanin-derived cryptides}

Hcs are acute phase proteins contributing to host recognition of non-self, pathogen opsonisation and agglutination, hemolysis, melanin biogenesis and virustasis, all of which have been reviewed in detail by Coates and Nairn (2014) [21]. The following section, however, is concerned primarily with the encrypted AMPs of Hc.

Hc-derived peptides were first isolated from hemolymph plasma of commercially relevant shellfish species, one from Litopenaeus vannamei ( $\mathrm{PvHCt}$ ) and two from $\mathrm{Pe}$ naeus stylirostris (Table 4) [177]. PvHCt failed to inhibit the growth of 17 bacterial species (both Gram $+/-$ ), yet revealed its exclusive antifungal activity at concentrations ranging from 3 to $50 \mu \mathrm{M}$ (Table 4). Most recently, the structure of PvHCt was solved using a combination of ${ }^{1} \mathrm{H}$ NMR and circular dichroism (Fig. 5). PvHCt is present in an unordered state in solution, and when incorporated into zwitterionic (DPC) micelles this histidine-rich peptide folds into a linear, amphipathic, $\alpha$-helical structure with an 
Table 3 Inducible $o$-diphenoloxidase activity in hemoglobin versus hemocyanin

\begin{tabular}{|c|c|c|c|c|}
\hline & \multicolumn{3}{|l|}{ Substrate kinetics } & \multirow[t]{2}{*}{ References } \\
\hline & Catechol & Dopamine & L-Dopa & \\
\hline \multicolumn{5}{|l|}{ Hemoglobins } \\
\hline Scapharca kagoshimensis & $\begin{array}{l}\mathrm{HbI}-K_{\mathrm{m}}=5.7 \mathrm{mM} \\
\mathrm{HbII}-K_{\mathrm{m}}=2.71 \mathrm{mM}\end{array}$ & - & $\begin{array}{l}\mathrm{HbI}-K_{\mathrm{m}}=2.0 \mathrm{mM} \\
\mathrm{HbII}-K_{\mathrm{m}}=1.22 \mathrm{mM}\end{array}$ & {$[145]$} \\
\hline Tegillarca granosa & $K_{\mathrm{m}}=0.097 \mathrm{mM}$ & - & $K_{\mathrm{m}}=1.44 \mathrm{mM}$ & [144] \\
\hline \multicolumn{5}{|l|}{ Hemocyanins } \\
\hline Charybdis japonica (A) & - & - & $K_{\mathrm{m}}=2.9 \mathrm{mM}$ & [172] \\
\hline $\begin{array}{l}\text { Eurypelma californicum } \\
\text { (A) }\end{array}$ & $K_{\mathrm{cat}} / K_{\mathrm{m}}=0.20 \pm 0.03 \mathrm{mM}^{-1}$ & $\begin{array}{l}V_{\max }=5.5 \pm 0.4 \mu \mathrm{M} \cdot \mathrm{s}^{-1} \\
K_{\mathrm{m}}=1.45 \pm 0.16 \mathrm{mM} \\
K_{\mathrm{cat}} / K_{\mathrm{m}}=3.91 \pm 0.55 \mathrm{mM} \cdot \mathrm{s}^{-1}\end{array}$ & $K_{\mathrm{cat}} / K_{\mathrm{m}}=0.59 \pm 0.08 \mathrm{mM} \cdot \mathrm{s}^{-1}$ & [168] \\
\hline Helix pomatia $(\mathrm{M})$ & $K_{\mathrm{m}}=2.6 \mathrm{mM}$ & - & - & {$[173]$} \\
\hline Helix vulgaris $(\mathrm{M})$ & & $\begin{array}{l}V_{\max }=0.137 \mathrm{mM} \mathrm{min}^{-1} \\
K_{\mathrm{m}}=2.86 \mathrm{mM}\end{array}$ & $\begin{array}{l}V_{\max }=0.018 \mathrm{mM} \mathrm{min}^{-1} \\
K_{\mathrm{m}}=0.77 \mathrm{mM}\end{array}$ & {$[25]$} \\
\hline Limulus polyphemus (A) & - & $\begin{array}{l}V_{\max }=4.7 \pm 0.2 \mu \mathrm{mol} \mathrm{min} \\
K_{\mathrm{m}}=1.3 \pm 0.1 \mathrm{mM}\end{array}$ & - & [170] \\
\hline Nephrops norvegicus (A) & 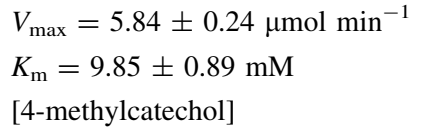 & $\begin{array}{l}V_{\max }=2.4 \pm 0.07 \mu \mathrm{mol} \mathrm{min} \\
K_{\mathrm{m}}=0.431 \pm 0.04 \mathrm{mM}\end{array}$ & - & {$[174]$} \\
\hline Panulirus argus (A) & $\begin{array}{l}V_{\max }=0.161 \pm 0.005 \Delta \mathrm{Abs} \\
\min ^{-1} \\
K_{\mathrm{m}}=7.174 \pm 0.487 \mathrm{mM}\end{array}$ & $\begin{array}{l}V_{\max }=0.143 \pm 0.003 \Delta \mathrm{Abs} \\
\min ^{-1} \\
K_{\mathrm{m}}=0.181 \pm 0.001 \mathrm{mM}\end{array}$ & $\begin{array}{l}V_{\max }=0.112 \pm 0.002 \Delta \mathrm{Abs} \\
\min ^{-1} \\
K_{\mathrm{m}}=2.565 \pm 0.115 \mathrm{mM}\end{array}$ & {$[175]$} \\
\hline Rapana venosa $\mathrm{FU}-\mathrm{a}(\mathrm{M})$ & - & $K_{\mathrm{m}}=6.53 \mathrm{mM}$ & $K_{\mathrm{m}}=2.0 \mathrm{mM}$ & {$[176]$} \\
\hline Sepia officinalis (M) & $K_{\mathrm{m}}=4.2 \mathrm{mM}$ & - & $K_{\mathrm{m}}=2.4 \mathrm{mM}$ & [173] \\
\hline
\end{tabular}

$A$ arthropod, $M$ mollusc

overall net-negative charge $(p I=6.16)$ (Fig. 5) [178]. Amphipathicity is a key feature of most pore-forming AMPs. Hyphae and spores of $F$. oxysporum were damaged irreversibly within $90 \mathrm{~min}$ of $\mathrm{PvHCt}(20 \mu \mathrm{M})$ treatment due to its gross accumulation on the exoplasmic side of the fungal cell wall, but were not dependent on interactions with ergosterol. Cellular pathologies included 'leakiness' (4 kDa flux), plasma membrane deterioration, fewer lipid bodies and effete mitochondria. A cationic peptide, termed FCHc-C2, was manufactured recombinantly from the cDNA of shrimp (Fenneropenaeus chinensis) Hc [179]. FCHc-C2 and PvHCt share high sequence homology $>90 \%$, the only differences being an aspartate is substituted with valine and a glycine is substituted with lysine (Table 4). Amphipathicity does not appear to differ significantly between these two peptides (Supp. Figure 2), yet unlike PvHCt, FCHc-C2 was active against Gram +/bacteria as well as fungi. The (conventional) basic charge of FCHc-C2 (aided by an additional histidine on the hydrophilic side of the helix) might permit non-selective electrostatic interactions with a broader range of microbes.

Other Hc-derived peptides, namely astacidin 1 and rondonin, were recovered from the hemolymph of immune- stimulated crayfish (Pacifastacus leniusculus [180]) and spiders (Acanthoscurria rondoniae [181]), respectively. In solution, astacidin 1 forms a $\beta$-sheet structure and is active against many bacteria [180] and fungi [182] (Table 4). These peptides are located on the surface of the Hcs and, therefore, exposed to the environment (Fig. 5 [21, 183]). Characterisations of truncated astacidin 1 variants revealed a dependency on the $\mathrm{N}$-terminal residues (FKVQNQHGQVVKIFHH-COOH) for effective microbe killing. Similar to PvHCt, astacidin 1 functions optimally at acidic $\mathrm{pH}$ and causes injury to the external membranes of fungi, creating trans-bilayer pores with radii $\sim 2 \mathrm{~nm}$. Rondonin, PvHCt and astacidin 1 all originated from the C-terminal domains (III) of their precursor Hcs, a structurally conserved region organised into a seven-stranded anti-parallel $\beta$-barrel (Figs. 1 and 5). Each peptide is likely detached from Hc via directed proteolysis. Aspartyl (pepstatin) and cysteine (E-64) protease inhibitors impeded the production of astacidin 1 in crayfish, indicating the peptide may be cleaved from $\mathrm{Hc}$ by cysteine-like proteases released by lysosomes [180]. Concentrations of Hc-derived AMPs in the hemolymph of shrimp and crayfish increased significantly in the presence of microbial ligands, LPS and 


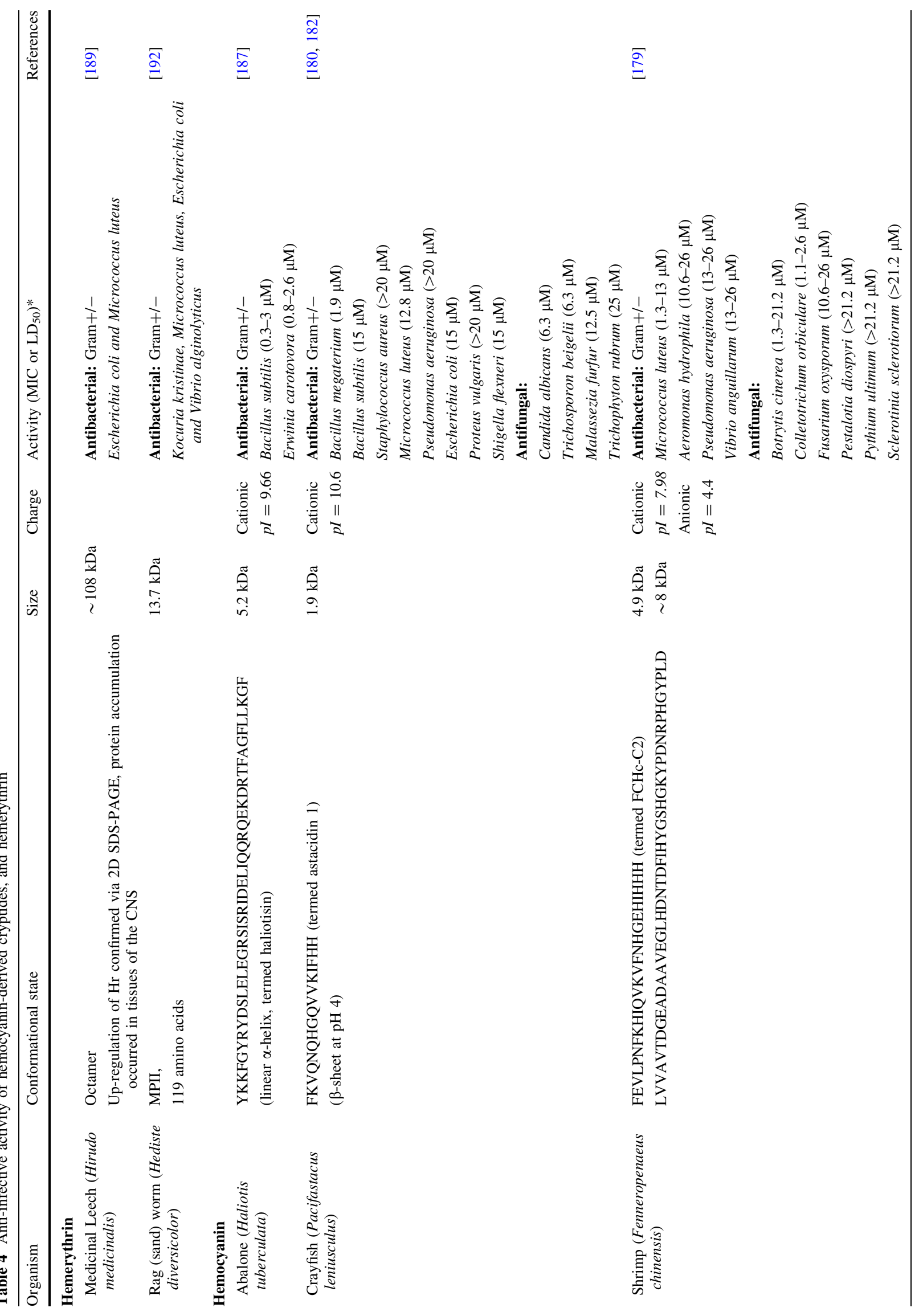




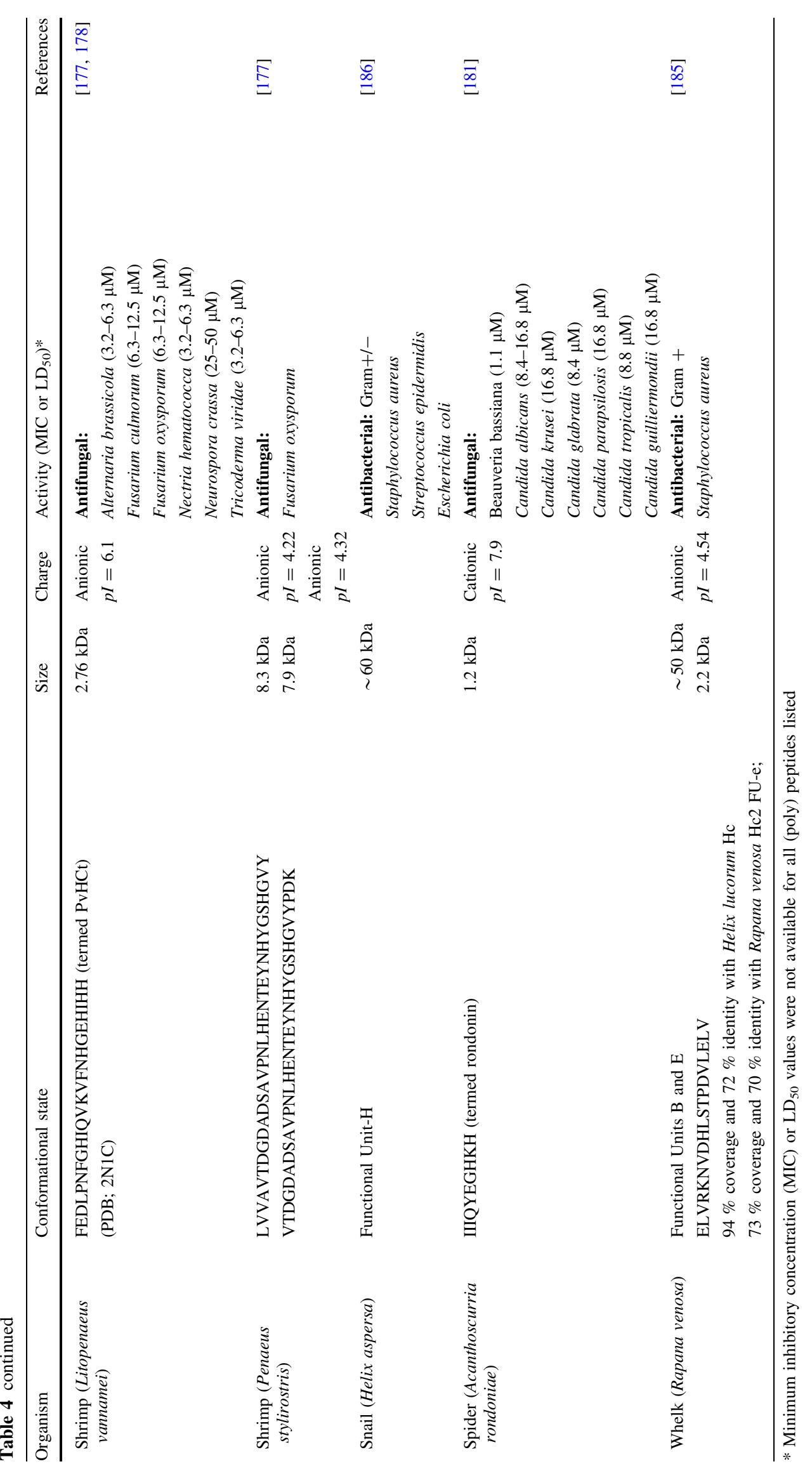




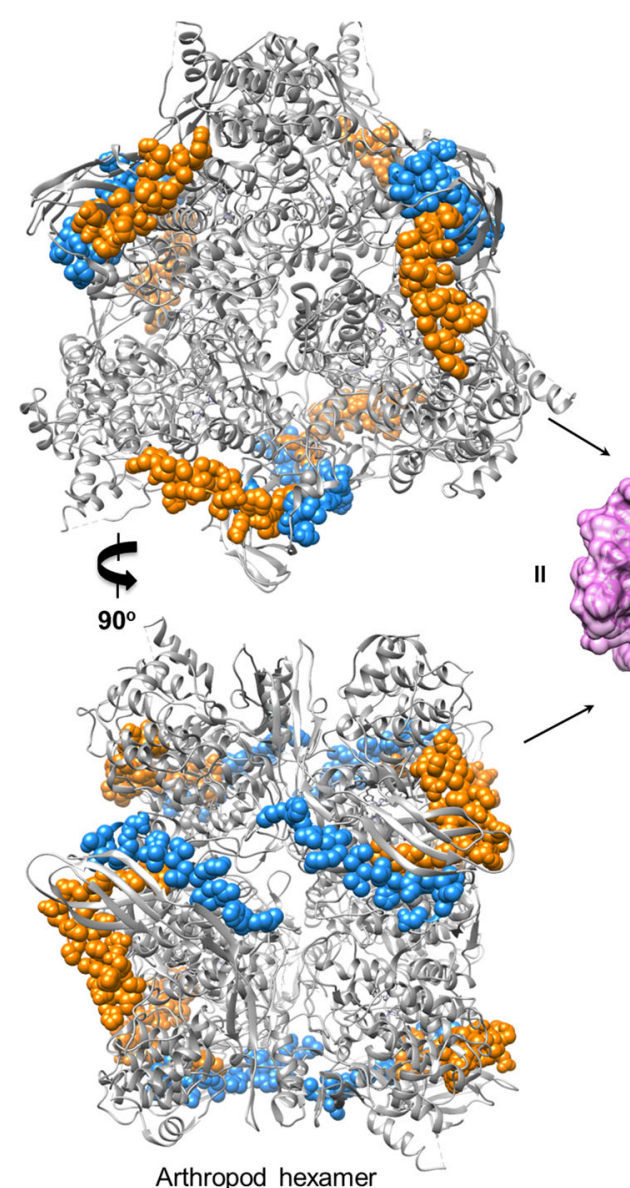

Arthropod hexamer

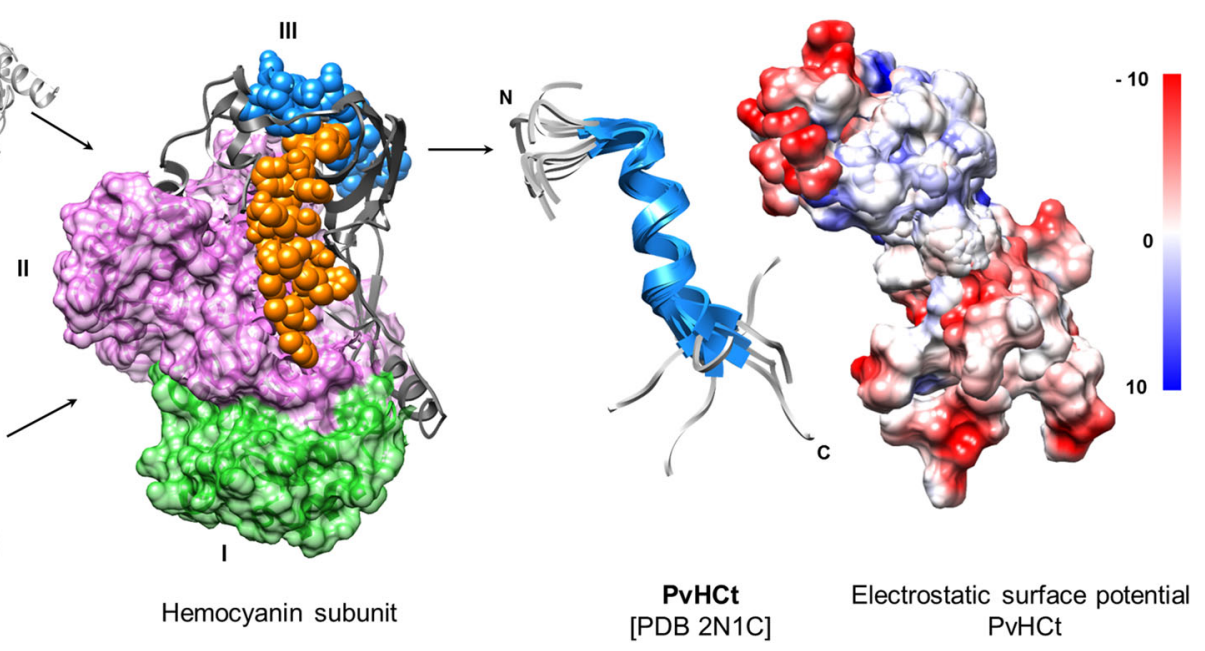

Fig. 5 Arthropod hemocyanin-derived antimicrobial peptides. The crystal structure of Panulirus interruptus hemocyanin (PDB 1HC1) is used to illustrate the location of the encrypted peptides: $\mathrm{PvHCt}$ (FEDLPNFGHIQVKVFNHGEHIHH: blue), astacidin 1 (FKVQNQHGQVVKIFHH: blue) from crayfish, and PsHCt2 (LVVAVTDGDADSAVPNLHENTEYNHYGSHGVY: orange) from shrimp on the hemocyanin hexamer ( $\sim 20 \mathrm{kDa})$ and corresponding subunit $(\sim 70 \mathrm{kDa})$. Hemocyanin subunit domains I and II are coloured green and purple, respectively. Both peptides are located on

$\beta$-glucan $[177,180]$. Therefore, Hc circulating freely in the haemolymph is an immediate source of immune mediators.

Although diverse antimicrobial and antiviral properties of mollusc Hc oligomers and several FUs have been noted [21, 184-186], mollusc Hc-derived peptides have received little attention. An interrogation of whelk (Rapana venosa) hemolymph led to the identification of a peptide with sequence similarities to a conserved motif at the N-terminus of many Hc FUs [185]. This whelk Hc-derived peptide did not inhibit the growth of $S$. aureus or Klebsiella pneumoniae; therefore, its physiological function is a mystery. An in silico study performed on abalone (Haliotis tuberculata) $\mathrm{Hc}$ indicated the region between the $\alpha$-helical and $\beta$-sandwich domains of FU-e contained encrypted AMPs [187]. A number of synthetic polypeptides resembling this region were antagonistic towards Erwinia the C-terminal subunit (III) of the hemocyanin where they can be liberated through proteolysis. The shrimp peptide $(\mathrm{PvHCt})$ is linear, $\alpha$-helical and amphipathic, with an overall net-negative charge (theoretical $p I=6.1$ ) as revealed by NMR. The electrostatic surface potential was calculated using UCSF Chimera [202]. PvHCt was isolated from Litopenaeus vannamei hemolymph and displays strict fungicidal activity. Both peptides are exposed to the environment even in the hexameric aggregation state. See also [21, 183]

carotovora and B. subtilis in vitro (Table 4). Membrane perturbations visible in electron micrographs of Hc-treated bacteria suggested the amphipathic peptide may act as a pore former. Predictive modelling of the strongest bioactive peptide (termed haliotisin; Table 4) revealed a linear, $\alpha$-helical structural conformation. Moreover, the peptide is positioned at the surface of the Hc protomer and is flanked by a series of trypsin and chymotrypsin cleavage sites, making it highly accessible during sepsis [187].

So far, no cysteine residues or disulphide bridges were found within any known Hc-derived AMP. This may be advantageous since the peptides can bind more easily to pathogens and be transported more readily through a membrane into the interior, rather than a stiff peptide. Each peptide contains at least three (up to eight) positively charged residues $(\mathrm{H}, \mathrm{R}, \mathrm{K})$ and differ substantially in their 
net electrical charges, $p I=4-11$ (Table 4; Fig. 5). The mode of action of Hc-derived AMPs may not be restricted to pore formation, as evidence discussed here hints to a possible role interfering with subcellular organelles.

\section{Hemerythrin and innate immunity}

$\mathrm{Hr}$ functionality is poorly characterised when compared to $\mathrm{Hb}$ and $\mathrm{Hc}$. Nevertheless, members of the $\mathrm{Hr}$ gene family, including myoHr, participate in respiration, heavy metal detoxification and aspects of innate immunity [188]. Responding to septic shock caused by E. coli and Micrococcus luteus, $\mathrm{Hr}$ expression increased significantly in the leech, Hirudo medicinalis [189]. Using a 2-DIGE approach, newly synthesised $\mathrm{Hr}$ accumulated within tissues of the central nervous system, referred to as neurohemerythrin. $\mathrm{Hr}$ expression was also spatially distributed in peripheral tissues such as muscle, the walls of blood vessels and nephridia (an excretory organ analogous to vertebrate kidneys). The dual functionality of $\mathrm{Hr}$ in leech immunity was contemplated; provision of oxygen to fuel the metabolic costs of immune activity, and the sequestration of iron needed by microbes to grow [189].

Metalloprotein II (MPII) is an antibacterial protein found in the coelomic fluid of Hediste (Nereis) diversicolor and other polychaetes [190-192]. It is a cadmium binding protein related to the $\mathrm{Hr}$ family, $\sim 81 \%$ similar to myoHr [193, 194], and can be produced within specialised coelomocytes (granulocytes type I), somatic muscle cells and the lining of the gut $[188,195]$. MPII and myoHr are monomeric isoforms of $\mathrm{Hr}$ subunits, displaying almost identical structural architecture (four $\alpha$-helix bundle). Upon immune stimulation with intact microbes (Vibrio alginolyticus, E. coli and M. luteus) or endotoxins, MPII is expelled into the coelomic fluid by granulocytes type I [192]. Concurrently, the enzyme PO is released by granulocytes type II. MPII likely provides the oxygen needed to catalyse phenol hydroxylation/oxidation, thereby facilitating the eventual biogenesis of melanin. This is quite interesting as $\mathrm{Hc}$ and $\mathrm{Hb}$ are also involved in converting phenols into (semi)quinone derivatives (see previous sections). The antibacterial properties of MPII are disrupted in the presence of iron or when the coelomic fluid is pre-treated with specific antibodies raised against MPII [192]. Certain sipunculids contain differential coelomocytes (pink blood cells) that express variants of $\mathrm{Hr}[5,196]$. Depending on their location within the body, cell-specific Hrs bind oxygen with varying affinities: low, moderate and high. Coelomocyte hematopoiesis following severe blood loss (exsanguination) in the peanut worm, Phascolosoma esculenta, accompanies the de novo synthesis of $\mathrm{Hr}$ [53]. Isoforms of $\mathrm{Hr}$ and myoHr have also been found in the salivary complex of the hematophagous leech, Haementeria depressa, and during anterior tissue regeneration of the earthworm, Perionyx excavatus [197, 198]. These data signify $\mathrm{Hr}$ is a multi-functional protein extending beyond its traditional role as a vehicle for molecular oxygen.

In 2011, a 10-kDa polypeptide was extracted from the exoskeleton of a baculovirus-infected crustacean, Pleuroncodes planipes [199]. Protein extracts were capable of inhibiting up to $99.5 \%$ of polyhedrosis nuclear virus replication. An acidic region of this polypeptide, VFYANLDEEHK, shared $100 \%$ coverage and 91-100\% amino acid sequence identity with $\mathrm{Hr}$-like protein subunits from annelids, Scoloplos armiger (Accession no. XP_013415662) and H. medicinalis (Accession no. Q674M7), and a brachiopod, Lingula anatina (Accession no. CAP08294). The authors compared their polypeptide to myoHr, yet in the absence of a known $\mathrm{Hr}$ within the Crustacea, caution and further information are required before categorising this protein as an immune effector.

The use of $\mathrm{Hr}$ as a defence strategy is not only employed by metazoan hosts. The aquatic pathogen, Aeromonas hydrophila, produces a single-domain $\mathrm{Hr}$ when inside the cytosol of Japanese eel macrophages to sense $\mathrm{O}_{2}$ and detoxify ROS [200]. Differential expression of $\mathrm{Hr}$ under extreme $\mathrm{O}_{2}$ conditions (hypoxic, hyperoxic) was recorded in wild-type A. hydrophila. The bacterium was also able to cope with high-level exposure to $\mathrm{H}_{2} \mathrm{O}_{2}$. Disruption of the $\mathrm{Hr}$ gene in A. hydrophila mutants (M85) led to a $77 \%$ reduction in survival when incubated with macrophages. Virulence of A. hydrophila is dependent on its ability to escape phagosomes using flagellar movements [201]. No differences in motility were found between the wild-type and $\mathrm{Hr}$ mutants; therefore, $\mathrm{Hr}$ is an important factor in $A$. hydrophila pathogenesis.

\section{Further considerations}

In many vertebrate and invertebrate systems, the presence of pathogens and parasites in the blood/hemolymph can lead to the de novo synthesis of OTPs ( $\mathrm{Hb}, \mathrm{Hc}$ and $\mathrm{Hr}$ ). Extracellular proteases that are secreted by microbes target $\mathrm{Hb}$ and $\mathrm{Hc}$, leading to the production of ROS/RNS, the conversion of phenolic substrates and release of encrypted immune peptides. The activities of OTP cryptides do not depend on their respective metal prosthetic groups. $\mathrm{Hb}$ in the absence of the heme cofactor retains its antimicrobial potency, and likewise, all Hc-derived AMPs originate from the C-terminal domains of arthropod $\mathrm{Hc}$ subunits and mollusc Hc functional units where they are not influenced by the distant dicopper centres located within the $\alpha$-helical structural domain. 
For each OTP there are many bona fide enzymes employing heme, di-iron or dicopper catalytic units: $\mathrm{Hb}-$ peroxidase and cytochrome $\mathrm{P} 450 ; \mathrm{Hc}$-tyrosinase and ascorbate oxidase; $\mathrm{Hr}$-ribonucleotide reductase and methane mono-oxygenase [4]. Therefore, is enzymatic activity or altered functionality of $\mathrm{Hb} / \mathrm{Hc} / \mathrm{Hr}$ a coincidence of subtle structural rearrangements or interchangeable roles in respiration, detoxification and immunity? A link between OTPs and immunity may be the mitigation or remediation of damage incurred by the host when mounting an immune response. RNS and ROS are equally harmful to the host as they are to microbes, highlighting the essential need for their production to be tightly regulated.

The evolution of OTPs is likely influenced by two coevolving systems: (1) optimising the precise delivery of dioxygen and storing it within cells (i.e. respiration), and (2) serving as an immediate and efficacious anti-infective agent (i.e. immunity).

Acknowledgments We would like to thank Swansea University (Biosciences) and the Immunology Centre, Mainz for their continued support.

\section{Compliance with ethical standards}

Conflict of interest We declare that no conflicts of interest, financial or other, exist.

Open Access This article is distributed under the terms of the Creative Commons Attribution 4.0 International License (http:// creativecommons.org/licenses/by/4.0/), which permits unrestricted use, distribution, and reproduction in any medium, provided you give appropriate credit to the original author(s) and the source, provide a link to the Creative Commons license, and indicate if changes were made.

\section{References}

1. Jonsson K, Hunt TK, Mathes SJ (1988) Oxygen as an isolated variable influences resistance to infection. Ann Surg 208:783-787

2. Schreml S, Szeimies RM, Prantl L, Karrer S, Landthaler M, Babilas P (2010) Oxygen in acute and chronic wound healing. Brit J Dermatol 163:257-268

3. Allen DB, Maguire JJ, Mahdavian M, Wicke C et al (1997) Wound hypoxia and acidosis limit neutrophil bacterial killing mechanisms. Arch Surg 132:991-996

4. Decker H, van-Holde KE (2010) Oxygen and the Evolution of Life. Springer, New York

5. Terwilliger NB (1998) Functional adaptations of oxygen-transport proteins. J Exp Biol 201:1085-1098

6. Royer WE, Strand K, van Heel M, Hendrickson WA (2000) Structural hierarchy in erythrocruorin, the giant respiratory assemblage of annelids. PNAS 97:7107-7111

7. Pallavicini A, Negrisolo E, Barbator R, Dewilde S, Ghiretti-Magaldi A, Moens L, Lanfranchi G (2001) The primary structure of globin and linker chains from the chlorocruorin of the polychaete Sabella spallanzanii. J Biol Chem 276:26384-26390
8. Riggs AF, Riggs CK (2014) The self-association of the giant hemoglobin from the earthworm, Lumbricus terrestris. Biochim Biophys Acta 1844:1071-1075

9. Hobson D, Hirsch JG (1958) The antibacterial activity of hemoglobins. J Exp Med 107:167-183

10. Burmester T, Hankeln T (2014) Function and evolution of vertebrate globins. Acta Physiol 211:501-514

11. Beutler E, Waalen J (2006) The definition of anemia: what is the lower limit of normal of the blood hemoglobin concentration? Blood 107:1747-1750

12. Yuan Y, Tam MF, Simplaceanu V, Ho C (2015) New look at hemoglobin allostery. Chem Rev 115:1702-1724

13. Wittenberg JB, Wittenberg BA (2003) Myoglobin function reassessed. J Exp Biol 206:2011-2020

14. Vinogradov SN (1985) The structure of invertebrate extracellular hemoglobins (erythrocruorins and chlorocruorins). Comp Biochem Physiol Part B 82:1-15

15. Ruggiero Bachega J, Vasconcelos Maluf F, Andi B, D’Muniz Pereira H, Falsarella Carazzollea M, Orville AM, Tabak M, Brandão-Neto J, Garratt RC, Horjales Reboredo E (2015) The structure of the giant haemoglobin from Glossoscolex paulistus. Acta Crystallogr D Biol Crystallogr 71:1257-1271

16. Van-Holde KE, Miller KI, Decker H (2001) Hemocyanins and invertebrate evolution. J Biol Chem 276:15563-15566

17. Markl J, Decker H (1992) Molecular structure of the arthropod hemocyanins. In Blood and tissue oxygen carriers (pp. 325-376). Springer Berlin Heidelberg

18. Hellmann N, Weber RE, Decker H (2003) Nested allosteric interactions in extracellular hemoglobin of the leech Macrobdella decora. J Biol Chem 278(45):44355-44360

19. Menze MA, Hellmann N, Decker H, Grieshaber MK (2005) Allosteric models for multimeric proteins: oxygen-linked effector binding in hemocyanin. Biochem 44:10328-10338

20. Coates CJ, Bradford EL, Krome C, Nairn J (2012) Effect of temperature on biochemical and cellular properties of captive Limulus polyphemus. Aquaculture 334-337:30-38

21. Coates CJ, Nairn J (2014) Diverse immune functions of hemocyanin. Dev Comp Immunol 45:43-55

22. Nagai T, Osaki T, Kawabata S (2001) Functional conversion of hemocyanin to phenoloxidase by horseshoe crab antimicrobial peptides. J Biol Chem 276:27166-27170

23. Lee SY, Lee BL, Söderhäll K (2004) Processing of crayfish hemocyanin subunits into phenoloxidase. Biochem Biophys Res Comm 322:490-496

24. Jiang N, Tan NS, Ho B, Ding JL (2007) Respiratory proteinmediated reactive oxygen species as an antimicrobial strategy. Nat Immunol 8:1114-1122

25. Hristova R, Dolashki A, Voelter W, Stevanovic S, DolashkaAngelova P (2008) o-Diphenol oxidase activity of molluscan hemocyanins. Comp Biochem Physiol Part B 149:439-446

26. Dolashka-Angelova P, Lieb B, Velkova L et al (2009) Identification of glycosylated sites in Rapana Hemocyanin by mass spectrometry and gene sequence, and their antiviral effect. Bioconjug Chem 20:1315-1322

27. Guo D, Zhang Y, Zeng D, Wang H, Li X, Li Y, Fan X (2009) Functional properties of hemocyanin from Oncomelania hupensis the intermediate host of Schistosoma japonicum. Exp Parasitol 123:277-281

28. Coates CJ, Kelly SM, Nairn J (2011) Possible role of phosphatidylserine-hemocyanin interaction in the innate immune response of Limulus polyphemus. Dev Comp Immunol 35:155-163

29. Coates CJ, Whalley T, Wyman M, Nairn J (2013) A putative link between phagocytosis-induced apoptosis and hemocyaninderived phenoloxidase activation. Apoptosis 18:1319-1331 
30. Schenk S, Schmidt J, Hoeger U, Decker H (2015) Lipoproteininduced phenoloxidase-activity in tarantula hemocyanin. Biochim Biophys Acta 1854:939-949

31. Lu X, Lu H, Guo L, Zhang Z et al (2015) Cloning and characterisation of a novel hemocyanin variant LvHMCV4 from shrimp Litopenaeus vannamei. Fish Shellfish Immunol 46:398-405

32. Sanggaard KW, Dyrlund TF, Bechsgaard JS, Scavenius C, Wang T, Bilde T, Enghild JJ (2016) The spider hemolymph clot proteome reveals high concentrations of hemocyanin and von Willebrand factor-like proteins. Biochim Biophys Acta 1864:233-241

33. Markl J (2013) Evolution of molluscan hemocyanin structures. Biochim Biophys Acta 1834:1840-1852

34. Gai Z, Matsuno A, Kato K, Kato S, Khan MRI, Shimizu T et al (2015) Crystal Structure of the 3.8-MDa Respiratory Supermolecule Hemocyanin at $3.0 \AA$ A Resolution. Structure 23:2204-2212

35. Gatsogiannis C, Moeller A, Depoix F, Meissner U, Markl J (2007) Nautilus pompilius hemocyanin: $9 \AA$ cryo-EM structure and molecular model reveal the subunit pathway and the interfaces between the 70 functional units. J Mol Biol 374:465-486

36. Gatsogiannis C, Hofnagel O, Markl J, Raunser S (2015) Structure of mega-hemocyanin reveals protein origami in snails. Structure 23:93-103

37. Arancibia S, Campo MD, Nova E, Salazar F, Becker MI (2012) Enhanced structural stability of Concholepas hemocyanin increases its immunogenicity and maintains its non-specific immunostimulatory effects. Eur J Immunol 42:688-699

38. Arancibia S, Espinoza C, Salazar F, Del Campo M, Tampe R, Zhong TY et al (2014) A Novel Immunomodulatory Hemocyanin from the Limpet Fissurella latimarginata Promotes Potent Anti-Tumor Activity in Melanoma. PLoS ONE 9(1):e87240

39. Guncheva M, Paunova K, Ossowicz P, Rozwadowski Z, Janus E, Idakieva $\mathrm{K}$ et al (2015) Modification of Rapana thomasiana hemocyanin with choline amino acid salts significantly enhances its antiproliferative activity against MCF-7 human breast cancer cells. RSC Adv 5:63345-63354

40. Guncheva M, Paunova K, Ossowicz P, Rozwadowski Z, Janus E, Idakieva $\mathrm{K}$ et al (2016) Rapana thomasiana hemocyanin modified with ionic liquids with enhanced anti breast cancer activity. Int J Biol Macro 82:798-805

41. Zanjani TN, Miranda-Saksena M, Valtchev P, Diefenbach RJ, Hueston L, Diefenbach E et al (2016) Abalone hemocyanin blocks the entry of herpes simplex virus 1 into cells. Antimicrob Agents Chemother 60:1003-1012

42. Moltedo B, Faunes F, Haussmann D, De Ioannes P, De Ioannes AE, Puente J, Becker MI (2006) Immunotherapeutic effect of Concholepas hemocyanin in the murine bladder cancer model: evidence for conserved antitumor properties among hemocyanins. J Urol 176:2690-2695

43. Swartz AM, Li QJ, Sampson JH (2014) Rindopepimut: a promising immuno-therapeutic for the treatment of glioblastoma multiforme. Immunotherapy 6:679-690

44. Sabbatini PJ, Ragupathi G, Hood C, Aghajanian CA, Juretzka M, Iasonos A et al (2007) Pilot study of a heptavalent vaccinekeyhole limpet hemocyanin conjugate plus QS21 in patients with epithelial ovarian, fallopian tube, or peritoneal cancer. Clin Cancer Res 13:4170-4177

45. Miles D, Roché H, Martin M, Perren TJ, Cameron DA, Glaspy J, Murray JL (2011) Phase III multicenter clinical trial of the sialyl-TN (STn)-keyhole limpet hemocyanin (KLH) vaccine for metastatic breast cancer. Oncologist 16:1092-1100

46. Zheng L, Zhao X, Zhang P, Chen C, Liu S, Huang R et al (2016) Hemocyanin from Shrimp Litopenaeus vannamei Has
Antiproliferative Effect against HeLa Cell In Vitro. PLoS ONE 11(3): $\mathrm{e} 0151801$

47. Antonova O, Dolashka P, Toncheva D, Rammensee HG, Floetenmeyer M, Stevanovic S (2014) In vitro antiproliferative effect of Helix aspersa hemocyanin on multiple malignant cell lines. Z Naturforsch C. 69:325-334

48. Gesheva V, Chausheva S, Mihaylova N, Manoylov I, Doumanova L, Idakieva K, Tchorbanov A (2014) Anti-cancer properties of gastropodan hemocyanins in murine model of colon carcinoma. BMC Immunol 15:34. doi:10.1186/s12865014-0034-3

49. Gesheva V, Chausheva S, Stefanova N, Mihaylova N, Doumanova L, Idakieva K, Tchorbanov A (2015) Helix pomatia hemocyanin-A novel bio-adjuvant for viral and bacterial antigens. Int Immunopharmacol 26:162-168

50. Stenkamp RE (1994) Dioxygen and Hemerythrin. Chem Rev 94:715-726

51. Bailly X, Vanin S, Chabasse C, Mizuguchi K, Vinogradov SN (2008) A phylogenomic profile of hemerythrins, the nonheme diiron binding respiratory proteins. BMC Evol Biol 8:244

52. Meyer A, Lieb B (2010) Respiratory proteins in Sipunculus nudus - Implications for phylogeny and evolution of hemerythrin family. Comp Biochem Physiol B 155:171-177

53. Liu Y, Li C, Su X, Wang M, Li Y, Li Y, Li T (2013) Cloning and characterisation of hemerythrin gene from Sipuncula Phascolosoma esculenta. Genes Genom 35:95-100

54. Okamoto Y, Onoda A, Sugimoto H, Takano Y, Hirota S, Kurtz DM Jr, Shiro Y, Hayashi T (2013) Crystal structure, exogenous ligand binding, and redox properties of an engineered diiron active site in a bacterial hemerythrin. Inorg Chem 52:13014-13020

55. Friesner RA, Baik MH, Gherman BF, Guallar V, Wirstam M, Murphy RB, Lippard SJ (2003) How iron-containing proteins control dioxygen chemistry: a detailed atomic level description via accurate quantum chemical and mixed quantum mechanics/molecular mechanics calculations. Coord Chem Rev 238-239:267-290

56. French CE, Bell JML, Ward FB (2008) Diversity and distribution of hemerythrin-like proteins in prokaryotes. FEMS Microbiol Lett 279:131-145

57. Manwell C, Baker CMA (1988) Magelona haemerythrin: tissue specificity, molecular weights and oxygen equilibria. Comp Biochem Physiol Part B 89:453-463

58. Vanin S, Negrisolo E, Bailly X, Bubacco L, Beltramini M, Salvato B (2006) Molecular evolution and phylogeny of Sipunculan hemerythrins. J Mol Evol 62:32-41

59. Ong ST, Ho JZS, Ho B, Ding JL (2006) Iron-withholding strategy in innate immunity. Immunobiol 211:295-314

60. Du R, Winarsih I, Ho B, Ding JL (2012) Lipid-free apolipoprotein A-I exerts an antioxidative role against cell-free hemoglobin. Am J Clin Exp Immunol 1:33-48

61. Lin T, Sammy F, Yang H, Thundivalappil S, Hellman J, Tracey KJ, Warren HS (2012) Identification of hemopexin as an antiinflammatory factor that inhibits synergy of hemoglobin with HMGB1 in sterile and infectious inflammation. J Immunol 189:2017-2022

62. Schaer DJ, Buehler PW, Alayash AI, Belcher JD, Vercellotti GM (2013) Hemolysis and free hemoglobin revisited: exploring hemoglobin and hemin scavengers as a novel class of therapeutic proteins. Blood 121:1276-1284

63. Atkinson SH, Uyoga SM, Nyatichi E, Macharia AW, Nyutu G, Ndila et al (2014) Epistasis between the haptoglobin common variant and a1 thalassemia influences risk of severe malaria in Kenyan children. Blood 27:2008-2016

64. Kato GJ (2009) Haptoglobin halts hemoglobin's havoc. J Clin Invest 119:2140-2142 
65. Schaer DJ, Alayash AI, Buehler PW (2007) Gating the radical hemoglobin to macrophages: the anti-inflammatory role of CD163, a scavenger receptor. Antioxid Redox Signal 9:991-999

66. Vanhollebeke B, De Muylder G, Nielsen MJ, Pays A, Tebabi P, Dieu M, Raes M, Moestrup SK, Pays E (2008) A haptoglobinhemoglobin receptor conveys innate immunity to Trypanosoma brucei in humans. Science 320:677-681

67. Alayash AI, Patel RP, Cashon RE (2001) Redox reactions of hemoglobin and myoglobin: biological and toxicological implications. Antioxid Redox Signal 3:313-327

68. Lee SK, Ding JL (2013) A perspective on the role of extracellular hemoglobin on the innate immune system. DNA Cell Biol 32:36-40

69. Gow AJ, Luchsinger BP, Pawloski JR, Singel DJ, Stamler JS (1999) The oxyhemoglobin reaction of nitric oxide. PNAS 96:9027-9032

70. Auten RL, Davis JM (2009) Oxygen toxicity and reactive oxygen species: the devil is in the details. Pediatr Res 66:121-127

71. James SL, Glaven J (1989) Macrophage cytotoxicity against schistosomula of Schistosoma mansoni involves arginine-dependent production of reactive nitrogen intermediates. J Immunol 143:4208-4212

72. Hahn UK, Bender RC, Bayne CJ (2001) Involvement of nitric oxide in killing of Schistosoma mansoni sporocysts by hemocytes from resistant Biomphalaria glabrata. J Parasitol 87:778-785

73. Ascenzi P, Fasano M, Gradoni L (2002) Do hemoglobin and hemocyanin impair Schistosoma killing by NO? IUBMB Life 53:287-288

74. Schwarzer E, Turrini F, Ulliers D, Giribaldi G, Ginsburg H, Arese P (1992) Impairment of macrophage functions after ingestion of Plasmodium falciparum-infected erythrocytes or isolated malarial pigment. J Exp Med 176:1033-1041

75. Schwarzer E, Alessio M, Ulliers D, Arese P (1998) Phagocytosis of the malarial pigment, hemozoin, impairs expression of major histocompatibility complex class II antigen, CD54, and CD11c in human monocytes. Infect Immun 66:1601-1606

76. Akira S, Hemmi H (2003) Recognition of pathogen-associated molecular patterns by TLR family. Immunol Let 85:85-95

77. Schechter AN (2008) Hemoglobin research and the origins of molecular medicine. Blood 112:3927-3938

78. Soares MP, Bozza MT (2016) Red alert: labile heme is an alarmin. Cur Opin Immunol 38:94-100

79. Yang H, Wang H, Bernik TR, Ivanova S, Ulloa L, Roth J, Eaton JW, Tracey KJ (2002) Globin attenuates the innate immune response to endotoxin. Shock 17:485-490

80. Du R, Ho B, Ding JL (2010) Rapid reprogramming of haemoglobin structure-function exposes multiple dual-antimicrobial potencies. EMBO J 29:632-642

81. Lee SK, Goh SY, Wong YQ, Ding L (2015) Response of neutrophils to extracellular haemoglobin and LTA in human blood system. EBioMedicine 2:225-233

82. Bahl N, Du R, Winarsih I, Ho B, Tucker-Kellogg L, Tidor B, Ding JL (2011) Delineation of lipopolysaccharide (LPS)-binding sites on hemoglobin: from in silico predictions to biophysical characterization. J Biol Chem 286:37793-37803

83. Lisk C, Kominsky D, Ehrentraut S, Bonaventura J, Nuss R, Hassell $\mathrm{K}$ et al (2013) Hemoglobin-induced endothelial cell permeability is controlled, in part, via a myeloid differentiation primary response gene-88-dependent signalling mechanism. Am J Respir Cell Mol Biol 49:619-626

84. Bahl N, Winarsih I, Tucker-Kellogg L, Ding JL (2014) Extracellular haemoglobin upregulates and binds to tissue factor on macrophages: implications for coagulation and oxidative stress. Thromb Haemost 111:67-78
85. Liu L, Zeng M, Stamler JS (1999) Hemoglobin induction in mouse macrophages. PNAS 96:6643-6647

86. Newton DA, Rao KMK, Dluhy RA, Baatz JE (2006) Hemoglobin is expressed by alveolar epithelial cells. J Biol Chem 281:5668-5676

87. Mak P (2008) Hemocidins in a functional and structural context of human antimicrobial peptides. Frontiers Biosci 13:6859-6871

88. Mak P, Wojcik K, Silberring J, Dubin A (2000) Antimicrobial peptides derived from heme-containing proteins: Hemocidins. Antonie von Leeuwenhoek 77:197-207

89. Parish CA, Jiang H, Tokiwa Y, Berova N et al (2001) Broadspectrum antimicrobial activity of hemoglobin. Bioinorg Med Chem 9:377-382

90. Ivanov VT, Karelin AA, Philippova MM, Nazimov IV, Pletnev VZ (1997) Hemoglobin as a source of endogenous bioactive peptides: The concept of tissue-specific peptide pool. Peptide Sci 43(2): 171-188

91. Fogaca AC, da Silva PI, Miranda MT et al (1999) Antimicrobial activity of a bovine hemoglobin fragment in the Tick Boophilus microplus. J Biol Chem 274:25330-25334

92. Nakajima Y, Ogihara K, Taylor D, Yamakawa M (2003) Antibacterial hemoglobin fragments from the midgut of the soft tick, Ornithodoros moubata (Acari: Argasidae). J Med Entomol 40:78-81

93. Sforca ML, Machado A, Figueredo RCR, Oyama S Jr, Silva FD, Miranda A, Daffre S, Miranda MTM, Spisni A, Pertinhez TA (2005) The micelle-bound structure of an antimicrobial peptide derived from the $\alpha$-chain of bovine hemoglobin isolated from the tick Boophilus microplus. Biochem 44:6440-6451

94. Liepke C, Baxmann S, Heine C et al (2003) Human hemoglobin-derived peptides exhibit antimicrobial activity: a class of host defense peptides. J Chromat B 791(1):345-356

95. Mak P, Wojcik K, Wicherek L, Suder P, Dubin A (2004) Antibacterial peptides in human menstrual blood. Peptides 25:1839-1840

96. Mak P, Wicherek L, Suder P, Dubin A, Banas T, Kaim I, Klimek M (2006) Analysis of free hemoglobin level and hemoglobin peptides from human puerperal uterine secretions. J Soc Gynecol Investig 13:285-391

97. Mak P, Siwek M, Pohl J, Dubin A (2007) Menstrual hemocidins $\mathrm{Hb} 115-146$ is an acidophilic antibacterial peptide potentiating the activity of human defensins, cathelicidin and lysozyme. Am J Reprod Immunol 57:81-91

98. Deng L, Pan X, Wang Y, Wang L, Zhou XE, Li M, Feng Y, Wu Q, Wang B, Huang N (2009) Hemoglobin and its derived peptides may play a role in the antibacterial mechanism of the vagina. Human Repro 24:211-218

99. Bochenska O, Rapala-Kozik M, Wolak N et al (2013) Secreted aspartic peptidases of Candida albicans liberate bactericidal hemocidins from human hemoglobin. Peptides 48:49-58

100. Froidevaux R, Krier F, Nedjar-Arroume N et al (2001) Antibacterial activity of a pepsin-derived bovine hemoglobin fragment. FEBS Letts 491:159-163

101. Daoud R, Dubois V, Bors-Dodita L, Nedjar-Arroune N, Krier F, Chihib N-E, Mary P, Kouach M, Briand G, Guillochon F (2005) New antibacterial peptide derived from bovine hemoglobin. Peptides 26:713-719

102. Machado A, Sforca ML, Miranda A, Daffre S, Pertinhez TA, Spisni A, Miranda MTM (2007) Truncation of the amidated fragment 33-61 of bovine $\alpha$-hemoglobin: effects on the structure and anticandidial activity. Biopolymers 88:413-426

103. Nedjar-Arroume N, Dubois-Delva V, Miloudi K, Daoud R, Krier F, Kouach M, Briand G, Guillochon D (2006) Isolation and characterization of four antibacterial peptides from bovine hemoglobin. Peptides 27:2082-2089 
104. Nedjar-Arroume N, Dubois-Delva V, Adje EY, Traisnel J, Krier F, Mary P, Kouach M, Briand G, Guillochon D (2008) Bovine hemoglobin: An attractive source of antibacterial peptides. Peptides 29:969-977

105. Carvalho LAC, Remuzgo C, Perez KR, Machini MT (2015) Hb40-61a: Novel analogues help expanding the knowledge on chemistry, properties and candidacidal action of this bovine $\alpha$ hemoglobin-derived peptide. Biochem Biophys Acta 1848:3140-3149

106. Bashir T, Patgaonkar M, Kumar S, Pasi A, Venkata K, Reddy R (2015) HbAHP-25, an in silico designed peptide, inhibits HIV-1 entry by blocking gp120 binding to CD4 receptor. PLoS ONE. doi:10.1371/journal.pone.0124839

107. Autelitano DJ, Rajic A, Smith AI, Berndt MC, Ilag LL, Vadas M (2006) The cryptome: a subset of the proteome, comprising cryptic peptides with distinct bioactivities. Drug Disc Today 11:306-314

108. Pimenta DC, Lebrun I (2007) Cryptides: Buried secrets in proteins. Peptides 28:2403-2410

109. Ner JH, Kotlinska J, Silberring J (2015) Crypteins-An Overlooked Piece of Peptide Systems. Curr Pept Prot Sci 16:203-218

110. Bellamy W, Takase M, Wakabayashi H, Kawase K, Tomita M (1992) Antibacterial spectrum of lactoferricin B, a potent bactericidal peptide derived from the $\mathrm{N}$-terminal region of bovine lactoferrin. J App Bacteriol 73:472-479

111. Gifford JL, Hunter HN, Vogel HJ (2005) Lactoferricin. Cell Mol Life Sci 62:2588-2598

112. Ibrahim HR, Inazaki D, Abdou A, Aoki T, Kim M (2005) Processing of lysozyme at distinct loops by pepsin: a novel action for generating multiple antimicrobial peptide motifs in the newborn stomach. Biochim Biophys Acta 1726(1):102-114

113. Mak P, Pohl J, Dubin A, Reed MS, Bowers SE, Fallon MT, Shafer WM (2003) The increased bactericidal activity of a fatty acid-modified synthetic antimicrobial peptide of human cathepsin $\mathrm{G}$ correlates with its enhanced capacity to interact with model membranes. Int J Antimicrob Agents 21(1):13-19

114. Arya S, Sethi D, Singh S, Hade MD, Singh V, Raju P, Chodisetti SB, Verma D, Varshney GC, Agrewala JN, Dikshit KL (2013) Truncated hemoglobin, $\mathrm{HbN}$, is post-translationally modified in Mycobacterium tuberculosis and modulates host-pathogen interactions during intracellular infection. J Biol Chem 288:29987-29999

115. Singh S, Thakur N, Oliver A, Petruk AA, Hade MD, Sethi D, Bidon-Chabal A, Marti MA, Datta H, Parkesh R, Estrin DA, Luque FJ, Dikshit KL (2014) Mechanistic insight into the enzymatic reduction of truncated hemoglobin $\mathrm{N}$ of Mycobacterium tuberculosis. J Biol Chem 289:21573-21583

116. Morera D, Roher N, Ribas L, Balasch JC, Doñate C, Callol A et al (2011) RNA-Seq reveals an integrated immune response in nucleated erythrocytes. PLoS ONE 6(10):e26998

117. Morera D, MacKenzie SA (2011) Is there a direct role for erythrocytes in the immune response? Vet Res 42:89

118. Fernandes JMO, Smith VJ (2004) Partial purification of antibacterial proteinaceous factors from the erythrocytes of Oncorhynchus mykiss. Fish Shellfish Immunol 16:1-9

119. Ullal AJ, Litaker RW, Noga EJ (2008) Antimicrobial peptides derived from hemoglobin are expressed in epithelium of channel catfish (Ictalurus punctatus, Rafinesque). Dev Comp Immunol 32:1301-1312

120. Ullal AJ, Noga EJ (2010) Antiparasitic activity of the antimicrobial peptide $\mathrm{Hb} \beta \mathrm{P}-1$, a member of the $\beta$-hemoglobin peptide family. J Fish Dis 33:657-664

121. Terova G, Cattaneo AG, Preziosa E, Bernardini G, Saroglia M (2011) Impact of acute stress on antimicrobial polypeptides mRNA copy number in several tissues of marine sea bass ( $D i$ centrarchus labrax). BMC Immunol 12(1):1
122. Meloni M, Candusso S, Galeotti M, Volpatti D (2015) Preliminary study on expression of antimicrobial peptides in European sea bass (Dicentrarchus labrax) following in vivo infection with Vibrio anguillarum. Fish Shellfish Immunol 43:82-90

123. Fan L, Wang A, Wu Y (2013) Comparative proteomic identification of the hemocyte response to cold stress in white shrimp, Litopenaeus vannamei. J Proteomics 80:196-206

124. Zhang DL, Guan RZ, Huang WS, Xiong J (2013) Isolation and characterization of antibacterial peptide derived from hemoglobin alpha in the liver of Japanese eel, Anguilla japonica. Fish Shellfish Immunol 35:625-631

125. Seo JK, Lee MJ, Jung HG, Go HJ, Kim YJ, Park NG (2014) Antimicrobial function of SH $\beta$ AP, a novel hemoglobin $\beta$ chainrelated antimicrobial peptide, isolated from the liver of skipjack tuna, Katsuwonus pelamis. Fish Shellfish Immunol 37:173-183

126. Conceição K, Monteiro-dos-Santos J, Seibert CS, Silva PI, Marques EE, Richardson M, Lopes-Ferreira M (2012) Potamotrygon cf. henlei stingray mucus: Biochemical features of a novel antimicrobial protein. Toxicon 60:821-829

127. Nigam AK, Kumari U, Mittal S, Mittal AK (20150 Evaluation of antibacterial activity and innate immune components in skin mucus of Indian major carp, Cirrhinus mrigala. Aquacul Res: $1-12$

128. Preecharram S, Jearranaiprepame P, Daduang S et al (2010) Isolation and characterisation of crocosin, an antibacterial compound from crocodile (Crocodylus siamensis) plasma. Animal Sci J 81(3):393-401

129. Kommanee J, Preecharram S, Daduang S, Temsiripong Y, Dhiravisit A, Yamada Y, Thammasirirak S (2012) Antibacterial activity of plasma from crocodile (Crocodylus siamensis) against pathogenic bacteria. Annals Clin Microbiol Antimicrobial 11(1):1

130. Srihongthong S, Pakdeesuwan A et al (2012) Complete amino acid sequence of globin chains and biological activity of fragmented crocodile hemoglobin (Crocodylus siamensis). Protein $\mathrm{J}$ $31: 466-476$

131. Maijaroen S, Anwised P, Klaynongsruang S, Daduang S, Boonmee A (2016) Comparison of recombinant $\alpha$-hemoglobin from Crocodylus siamensis expressed in different cloning vectors and their biological properties. Prot Expr Purific 118:55-63

132. Jandaruang J, Siritapetawee J, Thumanu K, Songsiriritthigul C et al (2012) The effects of temperature and $\mathrm{pH}$ on secondary structure and antioxidant activity of Crocodylus siamensis hemoglobin. Protein J 31:43-50

133. Hoffman, B.F., Key, B., Ofer, B., Kiryat, T., 2002. Reptilianderived peptides for the treatment of microbial infections. U.S. Patent No. 6,340,667. Washington, DC: U.S. Patent and Trademark Office

134. Lieb B, Dimitrova K, Kang H, Braun S et al (2006) Red blood with blue-blood ancestry: intriguing structure of snail hemoglobin. PNAS 103:12011-12016

135. Moeller V, Dürr R, Sarraf-Zadeh L, Keller S, Heinz S, Hellmann N, Moeller A, Lieb B, Markl J (2011) Recombinant functional multidomain hemoglobin from the gastropod Biomphalaria glabrata. IUBMB Life 63:323-328

136. Kokkinopoulou M, Güler MA, Lieb B, Barbeck M, Ghanaati S, Mark J (2014) 3D-ultrastructure, functions and stress responses of gastropod (Biomphalaria glabrata) rhogocytes. PLoS One 9(6):e101078. doi:10.1371/journal.pone.0101078

137. Kokkinopoulou M, Spiecker L, Messerschmidt C, Barbeck M, Ghanaati S, Landfester K, Markl J (2015) On the Ultrastructure and Function of Rhogocytes from the Pond Snail Lymnaea stagnalis. PLoS ONE 10:e0141195. doi:10.1371/journal.pone. 0141195

138. Dang C, Cribb TH, Osborne G, Kawasaki M, Bedin AS, Barnes AC (2013) Effect of a hemiuroid trematode on the hemocyte 
immune parameters of the cockle Anadara trapezia. Fish Shellfish Immunol 35:951-956

139. Bao Y, Wang Q, Lin Z (2011) Hemoglobin of the bloody clam Tegillarca granosa (Tg-HbI) is involved in the immune response against bacterial infection. Fish Shellfish Immunol 31:517-523

140. Bao Y, Wang Q, Guo XM, Lin ZH (2013) Structure and immune expression analysis of hemoglobin genes from blood clam Tegillarca granosa. Gen Mol Res 12:3110-3123

141. Bao Y, Li P, Dong Y et al (2013) Polymorphism of the multiple hemoglobins in blood clam Tegillarca granosa and its association with disease resistance to Vibrio parahaemolyticus. Fish Shellfish Immunol 34:1320-1324

142. Zhao X, Guo L, Zhang Y, Liu Y, Zhang X, Lun J, Chen J, Li Y (2012) SNPs of hemocyanin C-terminal fragment in shrimp Litopenaeus vannamei. FEBS Lett 586:403-410

143. Guo L, Zhao X, Zhang Y, Wang Z, Zhong M, Guo E, Li S, Lun J (2013) Evidences of SNPs in the variable region of hemocyanin Ig-like domain in shrimp Litopenaeus vannamei. Fish Shellfish Immunol 35:1532-1538

144. Bao Y, Wang J, Li C, Li P, Wang S, Lin Z (2016) A preliminary study on the antibacterial mechanism of Tegillarca granosa hemoglobin by derived peptides and peroxidase activity. Fish Shellfish Immunol 51:9-16

145. Xu B, Zhao J, Zhao J, Zhang Y, Shi Y, Fan T (2015) Role of hemoglobin from blood clam Scapharca kagoshimensis beyond oxygen transport. Fish Shellfish Immunol 44:248-256

146. Munoz P, Meseguer J, Esteban MÁ (2006) Phenoloxidase activity in three commercial bivalve species. Changes due to natural infestation with Perkinsus atlanticus. Fish Shellfish Immunol 20:12-19

147. Hellio C, Bado-Nilles A, Gagnaire B, Renault T, ThomasGuyon H (2007) Demonstration of a true phenoloxidase activity and activation of a ProPO cascade in Pacific oyster, Crassostrea gigas (Thunberg) in vitro. Fish Shellfish Immunol 22:433-440

148. Zhang Q, Xu Y, Wang Q, Hang B, Sun Y, Wei X, Hu J (2015) Potential of novel antimicrobial peptide $\mathrm{P} 3$ from bovine erythrocytes and its analogs to disrupt bacterial membranes in vitro and display activity against drug-resistant bacteria in a mouse model. Antimicrob Agents Chemo 59:2835-2841

149. Belmonte R, Cruz CE, Pires JR, Daffre S (2012) Purification and characterization of $\mathrm{Hb}$ 98-114: A novel hemoglobin-derived antimicrobial peptide from the midgut of Rhipicephalus (Boophilus) microplus. Peptides 37:120-127

150. Hu J, Xu M, Hang B, Wang L, Wang Q, Chen J, Song T, Fu D, Wang Z, Wang S, Liu X (2011) Isolation and characterization of an antimicrobial peptide from bovine hemoglobin $\alpha$-subunit. World J Microbiol Biotechnol 27:767-771

151. Mak P, Szewczyk A, Mickowska B, Kicinska A, Dubin A (2001) Effect of antimicrobial apomyoglobin 56-131 peptide on liposomes and planar lipid bilayer membrane. Int $\mathbf{J}$ Antimicro Agents 17:137-142

152. Cong Y, Zhang Q, Woolford D et al (2009) Structural mechanism of SDS-induced enzyme activity of scorpion hemocyanin revealed by electron cryomicroscopy. Structure 17:749-758

153. Cerenius L, Lee BL, Söderhäll K (2008) The pro-PO system: pros and cons for its role in invertebrate immunity. Trends Immunol 29:263-271

154. Sánchez-Ferrer Á, Rodríguez-López JN, García-Cánovas F, García-Carmona F (1995) Tyrosinase: a comprehensive review of its mechanism. Biochim Biophys Acta 1247:1-11

155. Decker H, Nillius Schweikardt T et al (2007) Similar enzyme activation and catalysis in hemocyanins and tyrosinases. Gene 398:183-191

156. Itoh S, Fukuzumi S (2007) Monooxygenase activity of type 3 copper proteins. Accounts Chem Res 40:592-600
157. Rolff M, Schottenheim J, Decker H, Tuczek F (2011) Copper-O 2 reactivity of tyrosinase models towards external monophenolic substrates: molecular mechanism and comparison with the enzyme. Chem Soc Rev 40:4077-4098

158. Adachi K, Wakamatsu K, Ito S et al (2005) An oxygen transporter hemocyanin can act on the late pathway of melanin synthesis. Pigm Cell Res 19:214-219

159. Goldfeder M, Kanteev M, Isaschar-Ovdat S, Adir N, Fishman A (2014) Determination of tyrosinase substrate-binding modes reveals mechanistic differences between type-3 copper proteins. Nat Comm 5

160. Kanteev M, Goldfeder M, Fishman A (2015) Structure-function correlations in tyrosinases. Protein Sci 24:1360-1369

161. Solem E, Tuczek F, Decker H (2016) Tyrosinase versus Catechol Oxidase: One Asparagine Makes the Difference. Angew Chem Int Ed 55:1-6

162. Decker H, Rimke T (1998) Tarantula hemocyanin shows phenoloxidase activity. J Biol Chem 273:25889-25892

163. Decker H, Ryan M, Jaenicke E, Terwilliger N (2001) SDSinduced phenoloxidase activity of hemocyanins from Limulus polyphemus, Eurypelma californicum and Cancer magister. J Biol Chem 276:17796-17799

164. Paul R, Bergner B, Pfeffer-Seidl A, Decker H, Efinger R, Storz $\mathrm{H}$ (1994) Gas transport in the haemolymph of arachnids-oxygen transport and the physiological role of haemocyanin. J Exp Biol 188:25-46

165. Adachi K, Endo H, Watanabe T, Nishioka T, Hirata T (2005) Hemocyanin in the exoskeleton of crustaceans: enzymatic properties and immunolocalization. Pigment Cell Res $18: 136-143$

166. Baird S, Kelly SM, Price NC, Jaenicke E, Meesters C, Nillius D, Decker H, Nairn J (2007) Hemocyanin conformational changes associated with SDS-induced phenol oxidase activation. Biochim Biophys Acta 1774:1380-1394

167. Goldfeder M, Egozy M, Ben-Yosef VS, Adir N, Fishman A (2013) Changes in tyrosinase specificity by ionic liquids and sodium dodecyl sulfate. Appl Microbiol Biotechnol 97:1953-1961

168. Jaenicke E, Decker H (2008) Kinetic properties of catecholoxidase activity of tarantula hemocyanin. FEBS J 275:1518-1528

169. Suzuki K, Shimokawa C, Morioka C, Itoh S (2008) Monooxygenase activity of Octopus vulgaris hemocyanin. Biochemistry 47:7108-7115

170. Wright J, McCaskill-Clark W, Cain JA, Patterson A, Coates CJ, Nairn J (2012) Effects of known phenoloxidase inhibitors on hemocyanin-derived phenoloxidase from Limulus polyphemus. Comp Biochem Physiol Part B 163:303-308

171. Cerenius L, Babu R, Söderhäll K, Jiravanichpaisal P (2010) In vitro effects on bacterial growth of phenoloxidase reaction products. J Invert Pathol 103:21-23

172. Fan T, Zhang Y, Yang L, Yang X, Jiang G, Yu M, Cong $R$ (2009) Identification and characterization of a hemocyaninderived phenoloxidase from the crab Charybdis japonica. Comp Biochem Physiol Part B 152:144-149

173. Siddiqui NI, Akosung RF, Gielens C (2006) Location of intrinsic and inducible phenoloxidase activity in molluscan hemocyanin. Biochem Biophys Res Com 348:1138-1144

174. Coates CJ, Nairn J (2013) Hemocyanin-derived phenoloxidase activity: A contributing factor to hyperpigmentation in Nephrops norvegicus. Food Chem 140:361-369

175. Perdomo-Morales R, Montero-Alejo V, Perera E, Pardo-Ruiz Z, Alonso-Jiménez E (2008) Hemocyanin-derived phenoloxidase activity in the spiny lobster Panulirus argus (Latreille, 1804). Biochim Biophys Acta 1780:652-658

176. Dolashki A, Voelter W, Dolashka P (2011) Phenoloxidase activity of intact and chemically modified functional unit RvH1- 
a from molluscan Rapana venosa hemocyanin. Comp Biochem Physiol Part B 1:1-7

177. Destoumieux-Garzon D, Saulnier D, Garnier J, Jouffrey C, Bulet P, Bachere E (2001) Crustacean immunity-antifungal peptides are generated from the $\mathrm{C}$-terminus of shrimp hemocyanin in response to microbial challenge. J Biol Chem 276:47070-47077

178. Petit VW, Rolland JL, Blond A, Cazevieille C, Djediat C, Peduzzi J, Goulard C, Bachere E, Dupont J, DestoumieuxGarzon D, Rebuffat S (2016) A hemocyanin-derived antimicrobial peptide from the penaeid shrimp adopts an alpha-helical structure that specifically permeabilizes fungal membranes. Biochim Biophys Acta 1860:557-568

179. Qiu C, Sun J, Liu M, Wang B, Jiang K, Sun S et al (2014) Molecular cloning of hemocyanin cDNA from Fenneropenaeus chinensis and antimicrobial analysis of two c-terminal fragments. Mar Biotechnol 16:46-53

180. Lee SY, Lee BL, Söderhäll K (2003) Processing of an antimicrobial peptide from hemocyanin of the freshwater crayfish Pacifastacus leniusculus. J Biol Chem 278:7927-7933

181. Riciluca KCT, Sayegh RSR, Melo RL, Silva PI Jr (2012) Rondonin an antifungal peptide from spider (Acanthoscurria rondoniae) haemolymph. Results Immunol 2:66-71

182. Choi H, Lee DG (2014) Antifungal activity and pore-forming mechanism of astacidin 1 against Candida albicans. Biochimie 105:58-63

183. Decker H, Jaenicke E (2004) Recent findings on phenoloxidase activity and antimicrobial activity of hemocyanins. Dev Comp Immunol 28:673-687

184. Dolashka P, Voelter W (2013) Antiviral activity of hemocyanins. Invertebr Surviv J 10:120-127

185. Dolashka P, Moshtanska V, Borisova V et al (2011) Antimicrobial proline-rich peptides from the hemolymph of marine snail Rapana venosa. Peptides 32:1477-1483

186. Dolashka P, Dolashki A, Van Beeumen J, Floetenmeyerd M, Velkova L, Stefanovic S, Voelter W (2016) Antimicrobial activity of molluscan hemocyanins from Helix and Rapana snails. Cur Pharmaceut Biotechnol. doi:10.2174/ 1389201016666150907113435

187. Zhuang J, Coates CJ, Zhu H, Zhu P, Wu Z, Xie L (2015) Identification of candidate antimicrobial peptides derived from abalone hemocyanin. Dev Comp Immunol 49:96-102

188. Yang D, Zhou Y, Zhao H, Zhou X, Sun N, Wang B, Yuan X (2012) Molecular cloning, sequencing, and expression analysis of cDNA encoding metalloproteins II (MPII) induced by single and combined metals $(\mathrm{Cu}(\mathrm{II}), \mathrm{Cd}(\mathrm{II}))$ in polychaete Perinereis aibuhitensis. Environ Toxicol Pharm 34:841-848

189. Vergote D, Sautiere PE, Vandenbulcke F (2004) Up-regulation of Neuro-hemerythrin expression in the central nervous system of the medicinal leech, Hirudo medicinalis, following septic injury. J Biol Chem 279:43828-43837

190. Dhainaut A, Raveillon B, M'Beri M, Porche-Hennere E, Demuynck S (1989) Purification of an antibacterial protein in the coelomic fluid of Nereis diversicolor (annelida, polychaeta). Similitude with a cadmium-binding protein. Comp Biochem Physiol Part C 94:555-560

191. Salzet-Raveillon B, Rentier-Delrue F, Dhainaut A (1993) Detection of mRNA encoding an antibacterial-metalloprotein
(MPII) by in situ hybridization with a cDNA probe generated by polymerase chain reaction in the worm Nereis diversicolor. Cell Mol Biol 39:105-114

192. Deloffre L, Salzet B, Vieau D, Andries J-C, Salzet M (2003) Antibacterial properties of Hemerythrin of the sand worm Nereis diversicolor. NEL 24:39-45

193. Demuynck S, Li KW, Van der Schors R, Dhainaut-Courtois N (1993) Amino acid sequence of the small cadmium-binding protein (MPII) from Nereis diversicolor (annelida, polychaeta). Evidence for a myohemerythrin structure. Eur J Biochem 215:151-156

194. Demuynck S, Bocquet-Muchembled B, Deloffre L, Grumiaux F, Lepretre A (2004) Stimulation by cadmium of myohemerythrinlike cells in the gut of the annelid Nereis diversicolor. J Exp Biol 207:1101-1111

195. Coutte L, Slomianny M-C, Malecha J, Baert J-L (2001) Cloning and expression analysis of a cDNA that encodes a leech hemerythrin. Biochim Biophys Acta 1518:282-286

196. Terwilliger NB, Terwilliger RC, Schabtach E (1985) Intracellular respiratory proteins of Sipuncula, Echiura and Annelida. In Blood Cells of Marine Invertebrates. Ed. Cohen, W., pp 193225. New York

197. Ricci-Silva ME, Konno K, Faria F, Radis-Baptista G, Fontes W, Stocklin R, Michalet S, Yamane T, Chudzinaki-Tavassi AN (2005) Protein mapping of the salivary complex from a hematophagous leech. OMICS J Integr Biol 9:194-208

198. Cho S-J, Lee MS, Tak ES, Lee E, Koh KS, Ahn CH, Park SC (2009) Gene expression profile in the anterior regeneration of the earthworm using expressed sequence tags. Biosci Biotechnol Biochem 73:29-34

199. Galvez-Romero G, Salas-Rojas M, Mendoza Hernandez G, Blanco-Favela F, Aguilar-Setien A (2011) Anti-baculovirus activity in a protein extracted from the exoskeleton of Pleuroncodes planipes [Decapoda: Galatheidae]. Fish Shellfish Immunol 31:482-484

200. Zeng WB, Chen WB, Yan QP, Lin GF, Qin YX (2016) Hemerythrin is required for Aeromonas hydrophila to survive in the macrophages of Anguilla japonica. Gen Mol Res 15; gmr15028074

201. Qin Y, Lin G, Chen W, Huang B, Huang W, Yan Q (2014) Flagellar motility contributes to the invasion and survival of Aeromonas hydrophila in Anguilla japonica macrophages. Fish Shellfish Immunol 39:273-279

202. Pettersen EF, Goddard TD, Huang CC, Couch GS, Greenblatt DM, Meng EC, Ferrin TE (2004) UCSF Chimera-a visualization system for exploratory research and analysis. J Comp Chem 25:1605-1612

203. Bechsgaard J, Vanthournout B, Funch P, Vestbo S, Gibbs RA, Richards $S$ et al (2016) Comparative genomic study of arachnid immune systems indicates loss of beta-1, 3-glucanase-related proteins and the immune deficiency pathway. J Evo Biol 29:277-291

204. Lorenzini DM, da Silva PI, Soares MB, Arruda P, Setubal J, Daffre S (2006) Discovery of immune-related genes expressed in hemocytes of the tarantula spider Acanthoscurria gomesiana. Dev Comp Immunol 30:545-556 